\title{
ANÁLISE SOBRE O CONHECIMENTO DE SITUAÇÕES DE ELISÃO E EVASÃO FISCAL DE ESTUDANTES DE CONTABILIDADE NA GRANDE SÃO PAULO
}

\author{
Nome \\ Marcelo Rabelo Henrique \\ Instituição/Afiliação \\ UNIFESP - Universidade Federal de São Paulo \\ País \\ Brasil \\ Contato principal para correspondência: mrhenrique@unifesp.br \\ Nome \\ Instituição/Afiliação \\ País \\ Nome \\ Instituição/Afiliação \\ País \\ Nome \\ Instituição/Afiliação \\ País \\ Natália Klengel Marques \\ UNIFESP - Universidade Federal de São Paulo \\ Brasil \\ Antônio Saporito \\ UNIFESP - Universidade Federal de São Paulo \\ Brasil \\ Sandro Braz Silva \\ UNIFESP - Universidade Federal de São Paulo \\ Brasil
}

\section{RESUMO}

Objetivo: É identificar o grau de acerto dos estudantes de contabilidade de cidades do estado de São Paulo em situações que simulam casos de elisão e evasão fiscal.

Método: Caracteriza-se quanto ao seu objetivo como uma pesquisa descritiva e, quanto aos procedimentos, como um estudo exploratório, por caracterizar um assunto de pesquisa com pouco conhecimento e de difícil formulação de hipóteses precisas e operacionalizáveis.

Originalidade / relevância: Para que os empresários possam gerenciar seus negócios de forma eficaz e proveitosa, faz-se necessário um cenário onde os profissionais que atuam na área tributária estejam preparados e instruídos a trabalhar com a legislação, o que não ocorre em alguns casos.

Resultados: Foi identificado através do estudo que o nível de conhecimento fiscal da amostra não é muito satisfatório, o que pode se relacionar com alguns fatores, como a baixa idade dos respondentes, que ainda não vivenciaram muitas situações práticas onde o conhecimento fiscal foi necessário, mesmo que a grande maioria dos estudantes se encontre na segunda metade do curso de graduação.

Contribuições teóricas / metodológicas: Considera-se a temática de suma relevância no meio acadêmico e empresarial, devido à necessidade da qualificação dos profissionais de contabilidade para um melhor conhecimento em situações práticas de planejamento tributário, principalmente para atender às demandas do mercado de trabalho.

Palavras chaves: Planejamento tributário. Elisão fiscal. Evasão fiscal. 


\section{ABSTRACT}

Objective: To identify the degree of correctness of accounting students from cities in the state of São Paulo in situations that simulate cases of tax avoidance and evasion.

Method: It is characterized in terms of its objective as a descriptive research and, in terms of procedures, as an exploratory study, as it characterizes a research subject with little knowledge and difficult to formulate precise and operable hypotheses.

Originality / relevance: For entrepreneurs to manage their businesses effectively and profitably, it is necessary to have a scenario where professionals working in the tax area are prepared and instructed to work with the legislation, which does not happen in some cases.

Results: It was identified through the study that the level of fiscal knowledge in the sample is not very satisfactory, which may be related to some factors, such as the low age of the respondents, who have not yet experienced many practical situations where fiscal knowledge was necessary, even if the vast majority of students are in the second half of the undergraduate course.

Theoretical / methodological contributions: It is considered the theme of utmost relevance in the academic and business environment, due to the need for the qualification of accounting professionals for better knowledge in practical situations of tax planning, mainly to meet the demands of the labor market.

Key words: Tax planning. Tax avoidance. Tax evasion.

\section{INTRODUÇÃO}

É conhecido que o Brasil é um dos países que mais arrecadam impostos do contribuinte, tanto em escala continental, como em escala global. Segundo a Receita Federal, no ano de 2016, a Carga Tributária Bruta (CTB) atingiu 32,38\% do Produto Interno Bruto - PIB, contra 32,11\% em 2015, o que faz com que as pessoas físicas e jurídicas se organizem cada vez mais em busca da redução dos impactos tributários sobre suas atividades, para que, acima de tudo, possam garantir sua sobrevivência.

Dentro deste cenário, surge o planejamento tributário como uma ferramenta essencial, principalmente a nível gerencial para as empresas, pois a partir dela as companhias podem reduzir seus dispêndios de maneira consciente, baseadas no conhecimento e exame da legislação vigente.

Silva (2012), o planejamento tributário é um meio de racionalização da atividade empresarial, que pode ser entendido como direito da empresa de planejar seus gastos tributários obtendo redução ou postergação dos gastos tributários, representando importante instrumento do aumento do resultado.

Assim, dentro do planejamento tributário, podem ser elencadas duas formas macro de organização das empresas com o objetivo de reduzir os encargos tributários: o método lícito, denominado elisão fiscal, e o método ilícito, comumente conhecido como evasão fiscal.

É importante ressaltar que a elisão fiscal nada se assemelha a sonegação fiscal, já que se trata de um estudo, onde o contribuinte planeja quando e como irá reduzir, retardar e até mesmo evitar o pagamento de tributos ao fisco.

Por outro lado, a evasão fiscal provém da palavra evadir, que é classificada como "esquivar (se) a dizer ou fazer alguma coisa; desviar, evitar" (Michaelis, 2018, p. 115). Esse método se baseia em manobras utilizadas para evitar o pagamento de impostos e pela violação frontal das leis tributárias, que pode ser classificada como sonegação fiscal.

Pohlmann (2010, p.15) explica, 
[...] manter-se atualizado a respeito das alterações da legislação tributária é fundamental para que um profissional possa alcançar sucesso nesse mercado. No Brasil, em especial, essa tarefa é extremamente trabalhosa e custosa, uma vez que o nosso sistema tributário é um dos mais complexos e intrincados do planeta.

Um fato importante a ser considerado, explicado por Abrahão (2011), é que a legislação brasileira é muito complexa e muda constantemente para sanar as chamadas "brechas" e outras falhas dentro da legislação, o que exige do profissional um estudo detalhado a fim de identificar a melhor alternativa legal para usufruir de benefícios.

Sendo assim, os profissionais que atuam nas áreas financeiras e estratégicas das entidades, conforme contexto mencionado deve buscar um elevado grau de eficiência no que tange ao conhecimento de formas de planejamento tributário, uma vez que esse planejamento faz com que o contribuinte possa tirar proveito dos benefícios fiscais expressamente previstos em lei. Não é sobre procurar lacunas na lei, mas sim ter a possibilidade de se beneficiar da mesma.

\subsection{Descrição do problema e questão de pesquisa}

A complexidade das leis brasileiras e a alta carga tributária faz com que a sonegação fiscal seja uma opção para a companhia, assim como a organização da unidade de negócio através de metodologia lícita. A gestão dos tributos por meio da elisão fiscal torna-se uma tarefa complicada e que exige um alto grau de conhecimento da lei, o que muitas vezes falta em uma empresa.

Para que os empresários possam gerenciar seus negócios de forma eficaz e proveitosa, faz-se necessário um cenário onde os profissionais que atuam na área tributária estejam preparados e instruídos a trabalhar com a legislação, o que não ocorre em alguns casos.

Sabendo que a elisão fiscal se apresenta como uma forma lícita de planejamento tributário, que a evasão fiscal se caracteriza como um método ilegal de não pagar o tributo, e que a diferença entre esses dois tratamentos pode por muitas vezes se apresentar de maneira sutil, surge o seguinte questionamento: Qual o nível de acerto dos estudantes de contabilidade em situações de elisão e evasão fiscal na grande São Paulo?

\subsection{Objetivos}

A seguir serão apresentados os objetivos gerais e os objetivos específicos que definem o rumo da pesquisa, a fim de alcançar as repostas ao problema proposto.

\subsection{Geral}

O objetivo geral desta pesquisa é identificar o grau de acerto dos estudantes de contabilidade de cidades do estado de São Paulo em situações que simulam casos de elisão e evasão fiscal.

\subsection{Específicos}

Para atingir o objetivo geral, esta pesquisa tratará dos seguintes objetivos específicos:

a) Realizar um breve levantamento bibliográfico sobre o sistema tributário nacional e planejamento tributário;

b) Apresentar a aplicação da pesquisa e os resultados sobre o grau de acerto dos estudantes de contabilidade da grande São Paulo sobre situações que diferenciam casos de elisão e evasão fiscal;

c) Relacionar as repostas dos estudantes de contabilidade com instituição de ensino, faixa etária e semestre do curso;

d) Apresentar as sugestões de melhoria para o ensino de temas tributários nas universidades, a partir das próprias sugestões propostas pelos estudantes. 


\subsection{Justificativa}

Várias razões justificam a realização de um estudo. Dentre as justificativas que contemplam esta pesquisa, podemos citar:

a) $\mathrm{O}$ fato de a lei estar em constante mudança, acompanhada pela evolução dos sistemas de informações, principalmente os instituídos pelo governo, o que faz com que os profissionais da área contábil estejam cada vez mais atualizados e busquem reciclarem seus conhecimentos, fato que poderá ser verificado com o resultado da pesquisa;

b) Contribuição e complementação de informações, com pontos de vista não abordados em estudos anteriores com temática de natureza similar;

c) A possibilidade de contribuir com a continuidade de trabalhos já realizados sobre a identificação de situações de elisão e evasão fiscal, que ocorreu no estado de Santa Catarina (Fonseca et al, 2015), apresentando resultados obtidos em uma diferente zona geográfica e relacionando seus efeitos com outro tipo de amostra (estudantes);

d) A avaliação do conhecimento de estudantes de contabilidade analisando como o sistema de ensino atual pode aprimorar o discernimento dos estudantes;

- A atividade tributária é uma opção de atuação profissional para diversos contadores.

\section{REFERENCIAL TEÓRICO}

O Sistema Tributário Nacional é formado por diversos princípios que limitam o exercício do poder imposto pelo governo, conforme explica Silva (2014): O Sistema Tributário Nacional, tal como existe atualmente, foi criado buscando harmonizar as relações da sociedade de forma a se atender aos seus princípios fundamentais, como também de forma a se respeitar o pacto federativo sob o qual vivemos.

A expressão STN engloba os tributos instituídos no país nas três esferas (União, Estado e Município), e todas as regras jurídicas e normas que podem relacionar a arrecadação desses tributos.

O Código Tributário Nacional - CTN, instituído pela Lei 5.172, de 10 de outubro de 1966, em seu artigo $2^{\circ}$ aborda o seguinte conceito:

O sistema tributário nacional é regido pelo disposto na Emenda Constitucional $\mathrm{n}^{\circ} 18$, de $1^{\circ}$ de dezembro de 1965, em leis complementares, em resoluções do Senado Federal e, nos limites das respectivas competências, em leis federais, nas Constituições e em leis estaduais, e em leis municipais.

Conforme a CF, no seu artigo 145, a União, os Estados, o Distrito Federal e os Municípios poderão instituir impostos, taxas e contribuição de melhoria. Assim, Souza, Nishina e Vieira (2016), explicam que podem ser criados impostos, taxas ou contribuições de melhoria conforme disposto na Constituição Federal, e que entidades dotadas do poder político para tal instituirão leis, estabelecendo limites para a realização da cobrança.

\subsection{Tributos}

Ainda considerando o Código Tributário Nacional - CTN, instituído pela Lei 5.172, de 10 de outubro de 1966, pode se definir o que é tributo através de seu $3^{\circ}$ artigo: "Tributo é toda prestação pecuniária compulsória, em moeda ou cujo valor nela se possa exprimir, que não constitua sanção de ato ilícito, instituída em lei e cobrada mediante atividade administrativa plenamente vinculada." (BRASIL, 1966) 
O conceito de tributo é considerado por alguns autores como o mais importante e complexo do CTN (Dutra, 2018; Abrahão, 2011), a razão se deve ao conceito do tributo. Devido a sua complexidade, busca-se os dizeres de Oliveira (2013), que sumarizou a definição de tributo da seguinte maneira:

Prestação pecuniária: significa que o tributo deve ser pago em unidades de moeda corrente, inexistindo o pagamento in natura ou in labore, ou seja, o que é pago em bens ou em trabalho de prestação de serviço;

Compulsória: obrigação independe da vontade do contribuinte; Em moeda ou cujo valor se possa exprimir: os tributos são expressos em moeda corrente nacional (reais) ou por meio de indexadores (ORTN, OTN, BTN, UFIR);

Que não constitua sanção de ato ilícito: as penalidades pecuniárias ou multas não se incluem no conceito de tributo; assim, o pagamento de tributo não decorre de infração de determinada norma ou descumprimento da lei;

Instituída em lei: só existe a obrigação de pagar o tributo se uma norma jurídica com força de lei estabelecer essa obrigação;

Cobrada mediante atividade administrativa plenamente vinculada: a autoridade não possui liberdade para escolher a melhor oportunidade de cobrar o tributo; a lei já estabelece todos os passos a serem seguidos.

Assim, pode-se dizer que o tributo é a parcela da renda ou patrimônio que o contribuinte deve pagar obrigatoriamente ao Estado, conforme previsto em lei, para que este possa realizar manutenções e desenvolvimento para a população.

O tributo deve ser pago em dinheiro, não sendo possível liquidar a dívida com outras formas de pagamento como móveis e veículos. Porém, há casos em que o pagamento de tributos com imóveis se torna viável (Cardoso, 2017).

Uma característica do tributo é sua compulsoriedade. Para todo tributo, há um fato que lhe dá origem (fato gerador).

\subsection{Espécies de tributos}

Conforme CF, no seu art.145, a União, os Estados, o Distrito Federal, e os Municípios poderão instituir os seguintes tributos: impostos, taxas e contribuição de melhoria. Texto semelhante ao art. $5^{\circ}$ do Código Tributário Nacional.

No entanto, ao se fazer uma análise nos artigos 145, 148 e 149 da CF, verifica-se que as espécies tributárias são cinco, a saber: o imposto, a taxa, a contribuição de melhoria (art. 145), o empréstimo compulsório (art. 148) e as contribuições especiais (art. 149 e 149-A) (Abrahão, 2011).

\subsection{Imposto}

Cardoso (2017), esclarece que os impostos, via de regra, incidem sobre o patrimônio, a renda e o consumo. O fato gerador dos impostos não está ligado a uma contraprestação, ou seja, não é diretamente vinculado a algo que o governo oferece em troca.

Os impostos podem incidir da seguinte forma:

Sobre o patrimônio: IPTU, IPVA.

Sobre a renda: IR, IRRF.

Sobre o consumo: IPI, ICMS, PIS, COFINS, ISS, calculados a cada item vendido ou serviço prestado.

A destinação do faturamento sobre os impostos é principalmente para o financiamento de serviços universais como educação, atendimento social à população, segurança, entre outros.

Abrahão (2011), explica que no recolhimento do imposto, o Estado não tem por obrigação oferecer ao contribuinte algum tipo de contraprestação direta e imediata, ou seja, o contribuinte pagou e sabe que não irá receber algo em troca de forma imediata por conta do pagamento deste tributo. 


\subsection{Taxas}

Conforme demonstrado por Soares (2017), diferente dos impostos, as taxas são vinculadas a uma contraprestação do Estado, como os serviços públicos, por exemplo, recolhimento de lixo ou emissão de documentos de um veículo.

É um valor cobrado por conta de uma prestação de serviços de um ente público, sejam eles municipal, federal ou estadual. Dele decorrem das atividades estatais, tais como os serviços públicos ou do exercício do poder de polícia, custas judiciais e a taxa de licenciamento de veículos taxam para emissão de um documento, taxa de limpeza pública etc.

De acordo com Nascimento (2018), as taxas não podem ter a base de cálculo nem o fato gerador iguais aos de um imposto, nem ser cobradas em função do capital das empresas. Podem ser criadas pelas três esferas de governo.

\subsection{Contribuições de melhoria}

As contribuições de melhoria, assim como as taxas, devem estar vinculadas a uma contraprestação estatal. É quando ocorre uma melhoria que resulte em benefício ao contribuinte, como quando é feito asfaltamento em uma rua, o valor do imóvel acaba aumentando por conta desta melhoria, implicando em valorização no imóvel do contribuinte. O cálculo do pagamento é feito com base no valor que será agregado a cada imóvel. As contribuições de melhoria podem ser instituídas pela União, pelos estados e pelos municípios (SOARES, 2018; CARDOSO, 2017).

\subsection{Empréstimos compulsórios}

Os empréstimos compulsórios são mais uma modalidade tributária prevista na Constituição Federal. Eles só podem ser criados pela União, por meio de lei complementar. Esse tipo de empréstimo tem como objetivo custear despesas excepcionais que, segundo o art. 148 da CF são:

I - para atender a despesas extraordinárias, decorrentes de calamidade pública, de guerra externa ou sua iminência;

II - no caso de investimento público de caráter urgente e de relevante interesse nacional, observado o disposto no art. 150, III, "b".

Ao contrário dos impostos, em que a arrecadação não é destinada para um fim específico, os recursos provenientes dos empréstimos compulsórios só podem ser utilizados na finalidade para a qual foram criados.

\subsection{Contribuição especial}

As contribuições especiais só podem ser instituídas pela União e, quando criadas, devem ter uma destinação ou finalidade específica. Nesse caso, a base de cálculo pode ser a mesma de um imposto, ou seja, o governo pode fazer uma dupla tributação.

A Constituição Federal prevê contribuições sociais (por exemplo, PIS/PASEP), profissionais, de intervenção no domínio econômico e de custo de serviço de iluminação pública.

De acordo com Oliveira (2013), este tipo de tributo foi criado com o intuito de ajudar financeiramente os órgãos previdenciários, assistenciais e das categorias profissionais, e também servem para custear o poder de controle do Estado junto a um determinado mercado e manter os órgãos de classe, como sindicatos ou conselhos que representam determinada área profissional.

\subsection{Obrigação tributária}

De acordo com o artigo 113 do CTN, o contribuinte pode ter dois tipos de obrigações tributárias: as acessórias e as principais.

Art. 113. A obrigação tributária é principal ou acessória. 
$\S 1^{\circ}$ A obrigação principal surge com a ocorrência do fato gerador, tem por objeto o pagamento de tributo ou penalidade pecuniária e extingue-se juntamente com o crédito dela decorrente.

$\S 2^{\circ}$ A obrigação acessória decorre da legislação tributária e tem por objeto as prestações, positivas ou negativas, nela previstas no interesse da arrecadação ou da fiscalização dos tributos.

$\S 3^{\circ}$ A obrigação acessória, pelo simples fato da sua inobservância, converte-se em obrigação principal relativamente à penalidade pecuniária.

Em suma, será principal a obrigação que tiver por objeto o pagamento, seja de tributo ou penalidade. Essa obrigação decorrerá conforme os apontamentos da lei. Será acessória a obrigação que tiver por objeto a realização de atos que auxiliem a Administração Tributária na fiscalização dos tributos, como: emissão de nota fiscal e declaração de imposto de renda. Explica Abrahão (2011): para que a obrigação tributária seja legalmente caracterizada, é necessário que se faça conhecer o seu fato gerador, o sujeito passivo e o sujeito ativo, constituindo-se estes elementos como básicos para a existência do tributo.

Cera (2010), explica que a obrigação tributária principal necessariamente deve estar prevista em lei, enquanto a obrigação tributária acessória estará prevista na legislação tributária.

Diante dos conceitos apresentados, pode-se concluir que há dois sujeitos da obrigação tributária, que é definida como o vínculo jurídico, e que une o sujeito ativo ao sujeito passivo, conferindo ao último o direito de constituir o crédito tributário (contribuinte).

O CTN, em seus artigos 121 e 122, explica que há a existência de dois sujeitos passivos, que são os da obrigação principal que também se divide entre contribuinte e responsável (a parte que legitima o fato gerador da obrigação tributária, e a segunda, como escolhida devedora da respectiva obrigação) e os da obrigação acessória.

\subsection{Planejamento tributário}

O Planejamento tributário surgiu como uma estratégia onde a empresa pode reduzir sua carga fiscal dentro de pretextos legais e aceitos por lei, exigindo um elevado conhecimento técnico.

Zanluca (2018): O planejamento tributário é um conjunto de sistemas legais que visam diminuir o pagamento de tributos. O contribuinte tem o direito de estruturar o seu negócio da maneira que melhor lhe pareça, procurando a diminuição dos custos de seu empreendimento, inclusive dos impostos. Se a forma celebrada é jurídica e lícita, a fazenda pública deve respeitá-la.

É conhecido que os impostos representam um importante percentual na hora de apurar o resultado da empresa, e conforme apresentado da introdução deste estudo, de acordo com a Receita Federal, no ano de 2016, a Carga Tributária Bruta (CTB) atingiu 32,38\% do Produto Interno Bruto PIB, contra 32,11\% em 2015. Ou seja, praticamente 1/3 da riqueza produzida pelo país é destinada ao Estado. Diante desse cenário, torna-se imprescindível a adoção de um sistema de economia legal, pois com isso pode-se entender o porquê da alta taxa de mortalidade precoce das empresas no Brasil.

Assim, diversos fatores devem ser considerados no planejamento dos tributos, pois como a legislação brasileira é complexa, muitos casos são aplicados em determinados cenários, mas não em outros. Faz-se necessário o levantamento de uma série de questões para se obter a melhor alternativa.

Para Benicio e Portela (2017), estudo da legislação em vigor, tipo de atividade prestada pela empresa, averiguação das vantagens e desvantagens nas formas de tributação existentes e saber quais podem ser aplicadas para o tipo específico de empresa; entre outros aspectos que necessitam ser verificados. 
É importante ressaltar que o planejamento tributário é um estudo preventivo, que analisa diversas alternativas legais de formalização jurídica de determinada operação antes da ocorrência do fato gerador do tributo, como uma forma de organização para o contribuinte.

Neste estudo sobre a economia de impostos, é importante que se tenha o conhecimento detalhado da lei, pois, muitas vezes, os dispositivos legais apresentam lacunas e brechas que podem ser utilizados para evitar o nascimento da obrigação tributária.

\subsection{Elisão fiscal}

Conforme apresentado por Tom (2017), a elisão fiscal é uma prática contábil que permite adequar uma empresa ao formato mais vantajoso de pagamento de impostos, sem que para isso seja cometida qualquer ilegalidade. A sua forma clássica atende também pelo nome de planejamento tributário, momento no qual é definido o regime adotado para o recolhimento dos tributos.

Zanluca (2018, p. 56), explica que a elisão fiscal pode ser caracterizada como uma gestão tributária inteligente que pode ser apresentada, basicamente, de duas formas:

Uma onde o próprio dispositivo legal permite ou até induz a economia dos tributos. Os incentivos fiscais são exemplos típicos de elisão induzida por lei, uma vez que ela já dá a seus contribuintes diversos benefícios.

A outra forma, conforme mencionada anteriormente, é através de lacunas e brechas da legislação, onde o contribuinte opta por configurar seus negócios de tal forma que se obtenha o menor ônus tributário, não se caracterizando como método proibido.

Para exemplificar um caso prático de elisão fiscal, utiliza-se o exemplo do imposto sobre serviços (ISS) cuja alíquota é de definição municipal, que também consta no questionário deste estudo (questões 1 e 2). A lei não apresenta proibição, para que os estabelecimentos mudem sua sede para a cidade vizinha, se ela pratica um percentual menor para esse tributo. É uma oportunidade se abre ao empreendedor, sem que sua decisão possa ser questionada.

Um outro caso de elisão fiscal, ocorre no momento da escolha do regime tributário (Simples Nacional, Lucro Real ou Presumido), onde se deve avaliar em qual cenário a empresa pode obter mais vantagens financeiras.

\subsection{Evasão fiscal}

Conforme demonstrado por Abrahão (2011, p.89), a evasão fiscal pode ser explicada como:

A evasão fiscal, ao contrário de elisão, consiste em prática que infringe as normas vigentes. Corresponde à sonegação ou fraude por parte do contribuinte, é um ato que busca economia de maneira ilícita na carga tributária. Na evasão fiscal a ilegitimidade se dá no ato do fato gerador e também após sua ocorrência, objetivando reduzir ou até mesmo ocultar a obrigação tributária.

A evasão fiscal acontece, por exemplo, quando um comerciante decide não declarar as vendas e serviços prestados por sua empresa para não exceder os limites que pertencem ao regime simplificado.

A omissão de informações (documentos fiscais), documentos com informações irreais, é um dos métodos de evasão mais utilizado. A evasão fiscal está prevista na Lei $\mathrm{n}^{\circ}$ 8.137/90, que define crimes contra a ordem tributária, econômica e contra as relações de consumo e estabelece crime $o$ ato de reduzir ou extinguir o tributo. A Lei $\mathrm{n}^{\circ} 8.137 / 90$ institui que:

Omitir informação ou prestar declaração falsa as autoridades fazendárias;

Fraudar a fiscalização tributária, inserindo elementos inexatos, ou omitindo operação de qualquer natureza, em documento ou livro exigido pela lei fiscal;

Falsificar ou alterar nota fiscal, fatura, duplicata, nota de venda, ou qualquer outro documento relativo à operação tributável;

Elaborar, distribuir, fornecer, emitir ou utilizar documento que saiba ou deva saber falso ou inexato; 
Utilizar ou divulgar programa de processamento de dados que permita ao sujeito passivo da obrigação tributária possuir informação contábil diversa daquela que é, por lei, fornecida à fazenda pública;

Fazer declaração falsa ou omitir declaração de rendas, bens ou fatos, ou empregar outra fraude, para eximir-se, total ou parcialmente, do pagamento de tributo.

Alguns casos práticos de evasão fiscal podem ser apresentados conforme Rizzi (2014), que exemplifica a situação em que a empresa possui uma filial, mas simula para o fisco que as unidades são empresas distintas, apenas para diminuir sua carga tributária.

Outro caso é quando a sonegação costuma ocorrer depois, como ao não declarar venda ou não emitir nota fiscal - ato comum na prática de caixa 2.

Segundo Abrahão (2011, p. 114):

A evasão fiscal pode ser culposa, que ocorre da ausência do conhecimento em pagar o tributo, ou dolosa, que é sempre ilícita e configura-se crime (fraude, sonegação, conluio). Nas infrações culposas, o contribuinte não tem a intenção de praticar o ato, mas o faz em decorrência de negligência, imprudência ou imperícia. Exemplo é o contribuinte que vende mercadorias e utiliza-se do modelo errado de nota fiscal para dar saída das mercadorias. As infrações dolosas envolvem a vontade do agente em praticar o ato.

\subsection{Conhecimento do contador em contabilidade tributária}

Para Zanluca (2018, p. 49),

[...] o contabilista é peça fundamental na elaboração e execução do planejamento tributário. Afinal, ele comanda uma série de operações internas da empresa, e normalmente, responsável por múltiplos controles, conciliações e apurações de impostos. O conhecimento na área tributária do profissional que realiza o planejamento tributário é extremamente importante. Sem informações contábeis adequadas, o planejamento tributário ficará dependente de dados incorretos, sujeitos a erros e avaliações equivocadas, e pode levar a ter problemas com o fisco, autuações, multas, comprometer a situação fiscal e financeira da empresa.)

O profissional contábil está diretamente relacionado com a crescente carga tributária brasileira, e o estudo do Direito Tributário torna-se essencial para estes profissionais buscarem imunidades, reduções, isenções e outros incentivos essenciais para a sobrevivência da empresa.

Lunelli (2018), explica que com o passar dos anos, a contabilidade tem sofrido constantes mutações, legais e práticas. Esta evolução surge da necessidade do mercado em receber informações cada vez mais detalhadas e hábeis para a tomada de decisões gerenciais, administrativas ou financeiras.

Esse avanço valoriza ainda mais o profissional contábil, que frente a estas mudanças, trata de se atualizar. A contabilidade tem hoje a missão de informar não somente dados fiscais, mas também aspectos econômicos e gerenciais aos quais a empresa está sujeita e tudo isto com a maior exatidão, clareza e velocidade possível.

Segundo Fonseca, Pilati e Theiss (2015), o Conselho Federal de Contabilidade (CFC) criou o Programa de Educação Continuada, que institui ao Contador, na função de Auditor Independente, e demais contadores que compõem seu quadro funcional técnico, aquisição de conhecimento por meio de cursos certificados, seminários, conferências, painéis, simpósios, palestras, congressos, convenções, cursos de extensão e cursos de pós-graduação (CFC 1.060/05 NBC P4).

O CFC garante, por meio do programa, que os profissionais se mantenham atualizados, o que permite uma melhor aplicabilidade da legislação tributária no momento do cumprimento das obrigações principais e acessórias da legislação tributária. Como consequência desta formação, o contador tem a oportunidade de adquirir conhecimento sistematizado sobre meios lícitos de redução de tributos.

\section{METODOLOGIA DA PESQUISA}


Este tópico objetiva descrever a metodologia empregada no decorrer da pesquisa. Em um primeiro momento, apresentam-se os conceitos de método e pesquisa, posteriormente, descreve-se a população definida, instrumento de coleta dos dados, e, após coleta, a análise dos dados obtidos.

O estudo objetiva avaliar qual o nível de acerto de contadores e estudantes de contabilidade em situações de elisão e evasão fiscal. Caracteriza-se quanto ao seu objetivo como uma pesquisa descritiva e, quanto aos procedimentos, como um estudo exploratório, por caracterizar um assunto de pesquisa com pouco conhecimento e de difícil formulação de hipóteses precisas e operacionalizáveis (GIL, 2010).

Com perguntas abertas e fechadas, o questionário foi elaborado por meio de pesquisas sobre situações de evasão e elisão fiscal. O questionário foi encaminhado aos estudantes de contabilidade da Grande São Paulo, por meio de questionários impressos, no período de agosto a novembro de 2018 (GIL, 2010).

Como técnica de observação foi aplicado um questionário, que busca, num primeiro momento, traçar o perfil dos respondentes, para assim auxiliar na análise dos resultados obtidos.

Após essa etapa, foram compostas perguntas assertivas em escala de Likert, onde para cada escolha é dada uma pontuação, que varia de 1 a 5 . Este recurso busca levantar as atitudes frente a um conjunto de assertivas, permitindo desde a concordância forte até a discordância forte das afirmações.

Para facilitar a análise dos resultados obtidos, foi explanado, no momento de aplicação do questionário, que a escala 1 mais se aproximava de questões onde a elisão fiscal era a resposta adequada, enquanto a aproximação a escala 5 demonstrava que o método de evasão fiscal era aplicado na simulação da situação.

Foram escolhidas questões abertas, que buscam obter as opiniões e percepções das pessoas em relação às simulações de situações de elisão e evasão fiscal. É importante ressaltar que o devido cuidado foi tomado para que a redação das questões fosse confeccionada de forma objetiva.

Por último foi aberta uma seção opcional no questionário, onde o estudante poderia informar até cinco pontos de melhoria para as condições de ensino de Contabilidade Tributária nas universidades.

Quanto à abordagem do problema, este estudo caracteriza-se com uma abordagem quantitativa, para Richardson (1989), "caracteriza-se pelo emprego da quantificação tanto nas modalidades de coleta de informações, quanto no tratamento dessas através de técnicas estatísticas, desde as mais simples, às mais complexas, como coeficiente de correlação, análise de regressão etc”. Para este estudo será aplicada a análise descritiva.

Para facilitar a visualização, apresenta-se na Tabela 1 o constructo da pesquisa, com as simulações dos casos que envolvem situações de elisão e evasão fiscal no que tange ao planejamento tributário. As simulações de tais situações foram extraídas do artigo de (Fonseca, Pilati, Theiss, 2015), onde as questões foram ocorridas ou exemplificadas em artigos e decisões de órgãos competentes.

Tabela 1: Constructo da pesquisa

\begin{tabular}{|l|c|c|}
\hline Questionamentos & $\begin{array}{c}\text { Supostas } \\
\text { Resposta }\end{array}$ & Autores \\
\hline 01. Conforme a Lei complementar 116, referente ISS, os serviços de informática e & Elisão & Silva (2012). \\
congêneres são serviços que o Imposto de ISS é pago no local da sede do prestador & Fiscal & \\
de serviços. Neste contexto, a empresa de informática de grande porte que se envolve & & \\
em contratos de altos valores, possui sua matriz localizada em um município com & \\
alíquota elevada de ISS. Como planejamento tributário, quando a alíquota de ISS & \\
é menor no local da prestação de serviço, a empresa monta uma sede de & \\
representação "Filial" e passa a emitir Nota Fiscal através da filial. & \\
\hline
\end{tabular}




\begin{tabular}{|c|c|c|}
\hline $\begin{array}{l}\text { 02. O serviço considera-se prestado e o imposto devido no local do estabelecimento } \\
\text { prestador ou, na falta do estabelecimento, no local do domićlio do prestador, exceto } \\
\text { nas hipóteses previstas nos incisos I a XXII (Lei Complementar } 116 \text { Art3). Uma } \\
\text { empresa de serviços de saúde, assistência médica e congênere, decide mudar sua } \\
\text { sede para o município vizinho, visando pagar ISS com uma alíquota menor. }\end{array}$ & $\begin{array}{l}\text { Elisão } \\
\text { Fiscal }\end{array}$ & $\begin{array}{l}\text { Zanluca } \\
\text { (2014). }\end{array}$ \\
\hline $\begin{array}{l}\text { 03. Uma empresa comercial do ramo de bebidas e frios finos, que atua no varejo e no } \\
\text { atacado, por comercializar bebidas alcoólicas no atacado está impedida de optar pelo } \\
\text { Simples Nacional (artigo 17, inciso X da Lei Complementar 123/06). A empresa } \\
\text { ocupa quatro áreas vizinhas de um centro comercial. O recolhimento dos tributos } \\
\text { pelo Lucro Presumido tem ocasionado alto custo da carga tributária. Como medida } \\
\text { de redução, o contador sugere como alternativa a reorganização societária, abertura } \\
\text { de uma nova empresa do Simples Nacional respeitando a LC 123/06 para venda no } \\
\text { varejo ocupando duas das áreas, continuando com a empresa anterior para vendas no } \\
\text { atacado excluindo a atividade de varejo nos outros dois espaços. }\end{array}$ & $\begin{array}{l}\text { Elisão } \\
\text { Fiscal }\end{array}$ & $\begin{array}{l}\text { De Luca, } \\
\text { Teixeira } \\
\text { Filho e } \\
\text { Corrêa } \\
\text { (2007). }\end{array}$ \\
\hline $\begin{array}{l}\text { 04. Conforme Lei Complementar } 123 / 06 \text {, as alíquotas do Simples Nacional são } \\
\text { progressivas de acordo com o valor do faturamento acumulado nos últimos } 12 \\
\text { meses. Para diminuir a carga tributária, determinada empresa através da } \\
\text { reorganização societária optou em desmembrar as atividades antes exercidas por uma } \\
\text { delas, instalando duas empresas optantes pelo Simples Nacional na mesma área } \\
\text { geográfica. Ambas as sociedades empresariais possuem registros e inscrições fiscais } \\
\text { próprias, quadro de funcionários diferentes e celebração de negócios separadamente. }\end{array}$ & $\begin{array}{l}\text { Elisão } \\
\text { Fiscal }\end{array}$ & $\begin{array}{l}\text { Dalmagro, } \\
\text { Martins } \\
(2011)\end{array}$ \\
\hline $\begin{array}{l}\text { 05. Determinada empresa que atua no ramo de indústria de móveis, ao chegar ao } \\
\text { limite do faturamento que permite continuar no Simples Nacional, decide criar } 3 \\
\text { empresas com o mesmo ramo de atividade, com endereços próximos, onde no } \\
\text { contrato social consta empregados como sócios, com intençâo de redução de tributos, } \\
\text { principalmente previdenciários. }\end{array}$ & $\begin{array}{c}\text { Evasão } \\
\text { Fiscal }\end{array}$ & $\begin{array}{l}\text { Ação Penal } \\
\text { N }^{\mathbf{0}} \text { 5001974- } \\
\text { 53.2011.404. } \\
7113 / \mathrm{RS} \\
(2013)\end{array}$ \\
\hline $\begin{array}{l}\text { 06. A constituição de duas empresas individuais, que ocupam um mesmo espaço } \\
\text { físico, desenvolve o mesmo objeto social, utilizam os mesmo colaboradores e } \\
\text { maquinários e, cujos sócios possuem grau de parentesco ou afinidade entre si, } \\
\text { objetivando reduzir custos, usufruir tributação privilegiada (Simples Nacional) e } \\
\text { pulverizar receitas, caracteriza a constituição de grupo econômico. }\end{array}$ & $\begin{array}{c}\text { Evasão } \\
\text { Fiscal }\end{array}$ & $\begin{array}{l}\text { Acórdão } \mathrm{N}^{\circ} \\
06-26037 \text { de } \\
01 \text { de Abril } \\
\text { de } 2010 \text {. }\end{array}$ \\
\hline $\begin{array}{l}\text { 07. Determinado grupo econômico, constituído por várias empresas optantes pelo } \\
\text { Simples Nacional, com estrutura autônoma tanto formal como material exercem } \\
\text { atividade econômica organizada de forma independente da empresa controladora. }\end{array}$ & $\begin{array}{l}\text { Elisão } \\
\text { Fiscal }\end{array}$ & Rizzi (2014). \\
\hline
\end{tabular}

Fonte: Identificação de situações de elisão e evasão fiscal: um estudo com contadores no estado de Santa Catarina

Para Malhotra (2001, p. 58), “a pesquisa exploratória é usada em casos nos quais é necessário definir o problema com maior precisão, identificar cursos relevantes de ação ou obter dados adicionais antes que se possa desenvolver uma abordagem".

A pesquisa de campo foi realizada através de aplicações de questionários impressos presencialmente em universidades onde o curso de Ciências Contábeis é ministrado. As universidades selecionadas foram UNIP, UNIFESP e ESAGS (FGV). O questionário foi aplicado em respondentes de diversos semestres de curso para que, assim, possam ser identificadas e justificadas possíveis discrepâncias nas respostas obtidas.

Após a fase de entrevistas, o autor do estudo em questão realizou a tabulação das respostas, foram obtidas 86 respostas ao todo, e a tabulação ocorreu por meio da utilização das ferramentas do programa Excel. Com a mensuração dos dados, fez-se necessário agrupá-los para análise, que apresentou informações mais relevantes. Com base nisso, foram verificadas diversas percepções a respeito do conhecimento dos entrevistados.

\section{ANÁLISE DE RESULTADOS}

Finda a revisão da literatura que conceitua o planejamento tributário e suas formas de organização, faz-se necessária a análise dos resultados obtidos através da aplicação de questionário para a amostra selecionada, com o objetivo de responder a questão principal da pesquisa, que é 


\section{Contabilidade}

identificar qual o grau de acerto dos contadores em simulações de situações de elisão e evasão fiscal.

A partir disso, foram analisados os níveis de conhecimento das simulações de situações de elisão e evasão fiscal de uma amostra e se verificou se fatores como faixa etária, instituição de ensino e semestre do curso influenciam seu nível de conhecimento fiscal. Foi aplicado um questionário com três partes: a primeira parte solicitando informações socioeconômicas do respondente, a segunda parte como um teste de conhecimento das situações anteriormente mencionadas, e, por último, foi aberta uma seção opcional no questionário, onde o estudante poderia informar até cinco pontos de melhoria para as condições de ensino de Contabilidade Tributária.

Essa pesquisa quantitativa envolveu 86 pessoas. Foi realizada por meio de aplicação dos questionários impressos fisicamente nas salas de aula e espaços comuns da Universidade Federal de São Paulo campus Osasco (UNIFESP), Universidade Paulista (UNIP) e Escola Superior de Administração e Gestão (ESAGS). O recebimento das respostas dos entrevistados deu-se entre os meses de agosto a novembro de 2018. O critério de seleção para a escolha destas pessoas considerou aqueles que estão matriculados nas universidades acima citadas.

Para melhor entendimento e organização dos dados, um breve contexto geral dos resultados obtidos será apresentado, e, posteriormente, as questões serão analisadas individualmente para que, finalmente, a conclusão da pesquisa possa ser verificada.

\subsection{Análise descritiva}

Conforme exposto, a pesquisa envolveu 86 respondentes, todos estudantes de Ciências contábeis da UNIFESP, UNIP e ESAGS. Foi realizada por meio da aplicação do questionário fisicamente nas salas de aula e espaços comuns das universidades mencionadas, e o subsequente recebimento da resposta dos entrevistados entre os meses de agosto a novembro de 2018.

Dos entrevistados neste trabalho, 38\% são estudantes da UNIFESP, 27\% da UNIP, $22 \%$ não informaram a instituição de ensino e 13\% são alunos do ESAGS conforme gráfico a seguir.

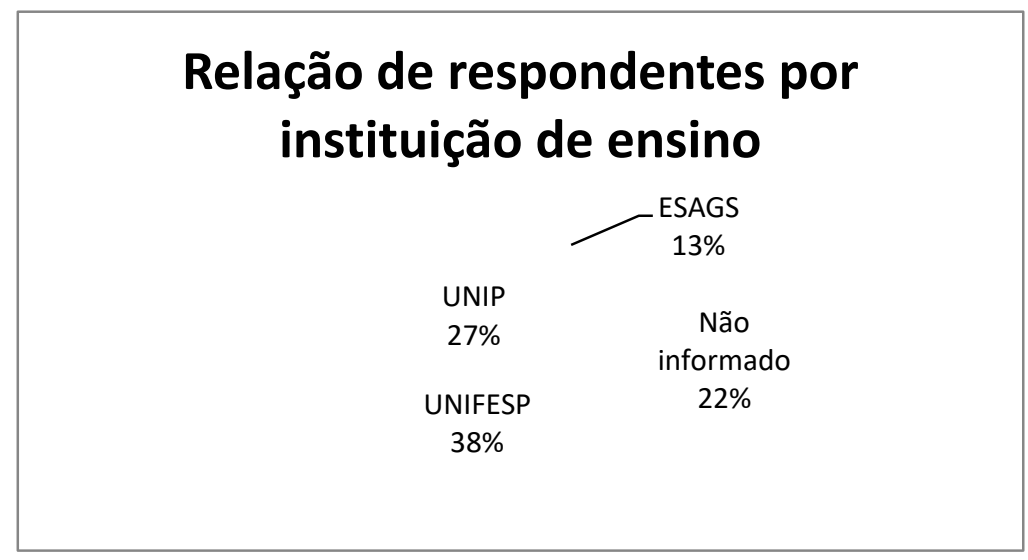

Gráfico 1: Relação respondentes por instituição de ensino Fonte: Próprio autor (2018).

$\mathrm{Na}$ sequência, foi necessário mensurar a faixa etária das pessoas que responderam à pesquisa. No gráfico abaixo, pode-se observar que a grande maioria delas (70\%) possui entre 21 e 30 anos.

A idade do entrevistado é de suma importância na presente análise, uma vez que os mais velhos, em teoria, possuem mais conhecimentos fiscais do que os mais novos, devido à própria 


\section{Contabilidade}

trajetória construída no mercado de trabalho e algumas obrigações com o Governo, como declarar seu próprio imposto de renda, por exemplo, embora essa suposição não seja uma regra.

Dessa forma, pode-se afirmar com segurança que, majoritariamente, as respostas foram obtidas de um público jovem, visto que logo na sequência temos as faixas etárias de 31 a 40 anos (14\%), até 20 anos de idade (13\%), mais que 41 anos (2\%) e idade não informada (1\%).

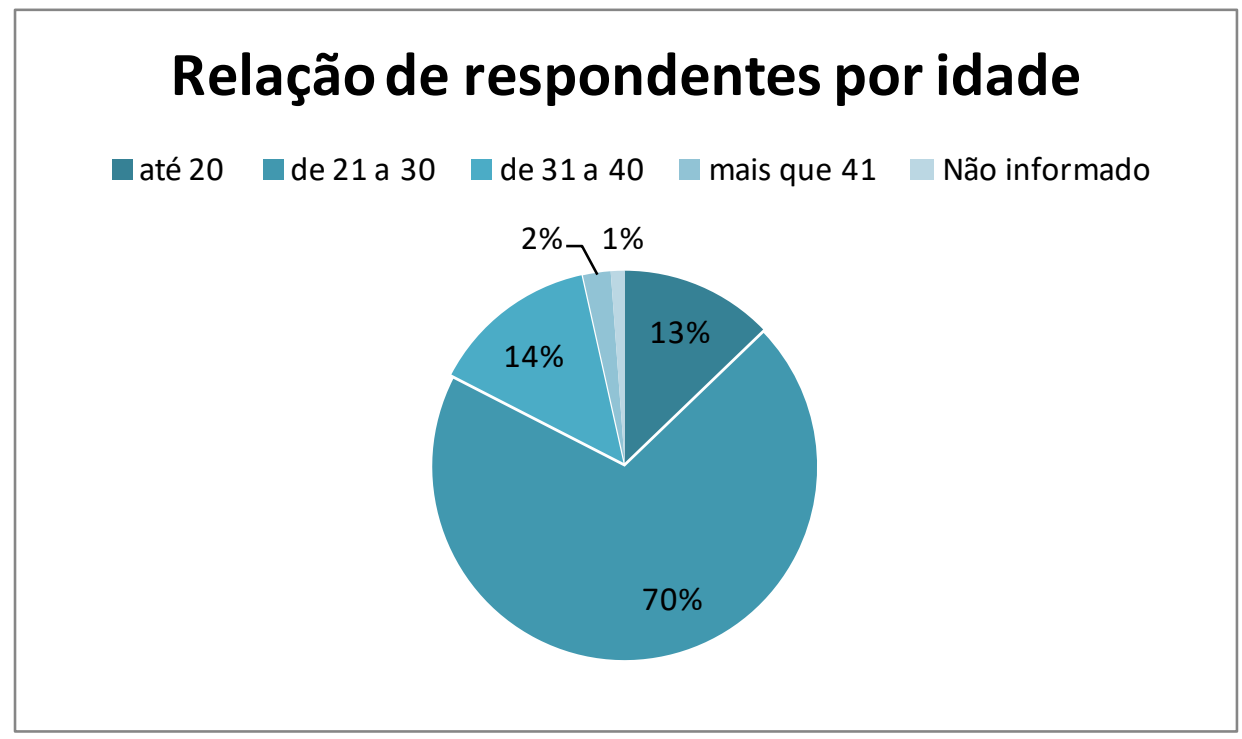

Gráfico 2: Relações Respondentes por idade

Fonte: Próprio autor (2018).

Todos os questionários foram aplicados para estudantes que cursam a partir do $3^{\circ}$ semestre do curso de Ciências Contábeis, embora haja um índice de respondentes que não informaram o semestre da graduação.

Com base nos resultados obtidos no que tange ao semestre do curso, podemos concluir que grande parte dos respondentes se encontra no final da graduação, o que pode ser um fator diretamente relacionado com os resultados obtidos no momento de apuração do resultado da pesquisa.

Um detalhe importante a ser ressaltado é que o curso da UNIFESP é o único que possui 5 anos para conclusão, ou seja, 10 semestres. Os demais são concluídos em 4 anos (semestres).

Assim, foi obtida a relação de respondentes versus semestre de graduação da seguinte forma: $8^{\circ}$ semestre $(57 \%), 7^{\circ}$ semestre $(17 \%), 6^{\circ}$ semestre $(9 \%), 4^{\circ}$ semestre $(6 \%)$, Não informado (5\%), $3^{\circ}$ semestre $(3 \%), 5^{\circ}$ semestre $(1 \%)$ e $10^{\circ}$ semestre $(1 \%)$.

O nível de escolaridade dos entrevistados é um fator importante para se estabelecer as primeiras suposições sobre a própria educação fiscal deles. Entende-se que quanto mais contato obteve-se com a grade do curso, maiores são as chances de extrair um resultado positivo na análise de resultados (acima de 50\% ao menos).

Antes de iniciar a análise das respostas individualmente para o entendimento das maiores dificuldades item a item, é importante informar de antemão que a média global de acerto das situações simuladas no questionário foi de $53 \%$, o que não é um resultado muito positivo, uma vez que a maioria dos estudantes já se encontra na segunda metade do curso de Ciências Contábeis, embora seja acima do mínimo esperado. O resultado talvez possa ser justificado pela pouca idade dos respondentes, que ainda não tiveram muito contato com questões fiscais ao longo da vida.

A metodologia considerada para obtenção do resultado global (assim como também será utilizada para análise de acerto das questões pontualmente) foi, através da escala de Likert, que 


\section{Contabilidade}

considera um intervalo de 1 a 5 . Este recurso busca levantar as atitudes frente a um conjunto de assertivas, permitindo desde a concordância forte até a discordância forte das afirmações.

Para facilitar a análise dos resultados obtidos, foi explanado, no momento de aplicação do questionário, que a escala 1 mais se aproximava de questões onde a elisão fiscal era a resposta adequada, enquanto a aproximação a escala 5 indicava que o método de evasão fiscal era aplicado na simulação da situação.

Assim, o questionário demonstra a seguinte percepção, para cada número deste intervalo (de 1 a 5): 1 (Concordo totalmente), 2 (Concordo parcialmente), onde estes mais se aproximam das situações de elisão fiscal (pelo fato de haver concordância com o método utilizado pela empresa, que é considerado como uma atividade lícita), enquanto 4 (Discordo parcialmente) e 5 (Discordo totalmente) mais se aproximam dos casos de evasão fiscal (onde a alternativa escolhida pela empresa é totalmente inadequada do ponto de vista legal).

Neste caso, a alternativa 3, (Não concordo nem discordo) é automaticamente desconsiderada para ambos os cenários (elisão e evasão), pois, ao ser considerada, ela aumenta a média global de acerto, enviesando o resultado obtido, uma vez que houve casos onde o respondente escolheu a alternativa 3 para praticamente todas as respostas do questionário, demonstrando falta de conhecimento sobre as situações expostas ou mero desinteresse para responder a pesquisa.

Dito isso, para reconhecimento global de acerto, a tabela abaixo demonstra o cálculo feito para obtenção dos $53 \%$. Foi considerada a seguinte metodologia para obtenção da média, tanto global, quanto a resposta para cada questão:

- os respondentes que indicaram a resposta correta para a situação indicada, Elisão fiscal, por exemplo, ao escolher a alternativa 1 , foi identificado que o respondente acertou $100 \%$ da questão, enquanto aquele que seleciona a alternativa 2 para a mesma questão, tem $75 \%$ de acerto, visto que a sua resposta ainda se aproxima da elisão fiscal, embora o estudante não concorde totalmente com a afirmação. Por outro lado, para aqueles que escolheram as alternativas 3, 4 e 5 para este caso, não possuem percentual algum de acerto;

- os respondentes que indicaram a resposta correta para a situação indicada, Evasão fiscal, por exemplo, ao escolher a alternativa 5 para a situação, obteve $100 \%$ do acerto, enquanto aquele que selecionou a alternativa 4 , obteve $75 \%$ de acerto visto que a sua resposta ainda se aproxima de evasão fiscal, embora o estudante não concorde totalmente com a afirmação. Por outro lado, para aqueles que escolheram as alternativas 3, 2 e 1 para o mesmo caso, não possuem percentual algum de acerto.

Tabela 2: Cálculo da média global de acerto das situações simuladas

\begin{tabular}{|c|c|c|c|c|}
\hline Questão 1 - Elisão & Respondentes & \% & \% Acerto & \% Acerto total \\
\hline Não respondeu & 1 & $1 \%$ & $0 \%$ & $0 \%$ \\
\hline Opção 1 & 37 & $43 \%$ & $100 \%$ & $43 \%$ \\
\hline Opção 2 & 15 & $17 \%$ & $75 \%$ & $13 \%$ \\
\hline Opção 3 & 12 & $14 \%$ & $0 \%$ & $0 \%$ \\
\hline Opção 4 & 11 & $13 \%$ & $0 \%$ & $0 \%$ \\
\hline Opção 5 & 10 & $12 \%$ & $0 \%$ & $0 \%$ \\
\hline \multicolumn{7}{|c|}{ 1) Elisão 56\% } & \\
\hline Questão 2 - Elisão & Respondentes & $\%$ & \% Acerto & \% Acerto total \\
\hline Opção 1 & 35 & $41 \%$ & $100 \%$ & $41 \%$ \\
\hline Opção 2 & 30 & $35 \%$ & $75 \%$ & $26 \%$ \\
\hline Opção 3 & 8 & $9 \%$ & $0 \%$ & $0 \%$ \\
\hline Opção 4 & 4 & $5 \%$ & $0 \%$ & $0 \%$ \\
\hline
\end{tabular}




\begin{tabular}{|c|c|c|c|c|}
\hline Opção 5 & 9 & $10 \%$ & $0 \%$ & $0 \%$ \\
\hline \multicolumn{5}{|c|}{ 2) Elisão $67 \%$} \\
\hline Questão 3 - Elisão & Respondentes & $\%$ & $\%$ Acerto & $\%$ Acerto total \\
\hline Opção 1 & 14 & $16 \%$ & $100 \%$ & $16 \%$ \\
\hline Opção 2 & 27 & $31 \%$ & $75 \%$ & $24 \%$ \\
\hline Opção 3 & 14 & $16 \%$ & $0 \%$ & $0 \%$ \\
\hline Opção 4 & 8 & $9 \%$ & $0 \%$ & $0 \%$ \\
\hline Opção 5 & 23 & $27 \%$ & $0 \%$ & $0 \%$ \\
\hline \multicolumn{5}{|c|}{ 3) Elisão $40 \%$} \\
\hline Questão 4 - Elisão & Respondentes & $\%$ & $\%$ Acerto & $\%$ Acerto total \\
\hline Opção 1 & 24 & $28 \%$ & $100 \%$ & $28 \%$ \\
\hline Opção 2 & 23 & $27 \%$ & $75 \%$ & $20 \%$ \\
\hline Opção 3 & 18 & $21 \%$ & $0 \%$ & $0 \%$ \\
\hline Opção 4 & 7 & $8 \%$ & $0 \%$ & $0 \%$ \\
\hline Opção 5 & 14 & $16 \%$ & $0 \%$ & $0 \%$ \\
\hline \multicolumn{5}{|c|}{ 4) Elisão $48 \%$} \\
\hline Questão 5 - Evasão & Respondentes & $\%$ & $\%$ Acerto & $\%$ Acerto total \\
\hline Opção 1 & 12 & $14 \%$ & $0 \%$ & $0 \%$ \\
\hline Opção 2 & 5 & $6 \%$ & $0 \%$ & $0 \%$ \\
\hline Opção 3 & 12 & $14 \%$ & $0 \%$ & $0 \%$ \\
\hline Opção 4 & 14 & $16 \%$ & $75 \%$ & $12 \%$ \\
\hline Opção 5 & 43 & $50 \%$ & $100 \%$ & $50 \%$ \\
\hline \multicolumn{5}{|c|}{ 5) Evasão 62\% } \\
\hline Questão 6 - Evasão & Respondentes & $\%$ & $\%$ Acerto & $\%$ Acerto total \\
\hline Opção 1 & 14 & $16 \%$ & $0 \%$ & $0 \%$ \\
\hline Opção 2 & 7 & $8 \%$ & $0 \%$ & $0 \%$ \\
\hline Opção 3 & 11 & $13 \%$ & $0 \%$ & $0 \%$ \\
\hline Opção 4 & 21 & $24 \%$ & $75 \%$ & $18 \%$ \\
\hline Opção 5 & 33 & $38 \%$ & $100 \%$ & $38 \%$ \\
\hline \multicolumn{5}{|c|}{ 6) Evasão 57\% } \\
\hline Questão 7 - Elisão & Respondentes & $\%$ & $\%$ Acerto & $\%$ Acerto total \\
\hline Opção 1 & 19 & $22 \%$ & $100 \%$ & $22 \%$ \\
\hline Opção 2 & 25 & $29 \%$ & $75 \%$ & $22 \%$ \\
\hline Opção 3 & 15 & $17 \%$ & $0 \%$ & $0 \%$ \\
\hline Opção 4 & 10 & $12 \%$ & $0 \%$ & $0 \%$ \\
\hline Opção 5 & 17 & $20 \%$ & $0 \%$ & $0 \%$ \\
\hline \multicolumn{5}{|c|}{ 7) Elisão 44\% } \\
\hline
\end{tabular}




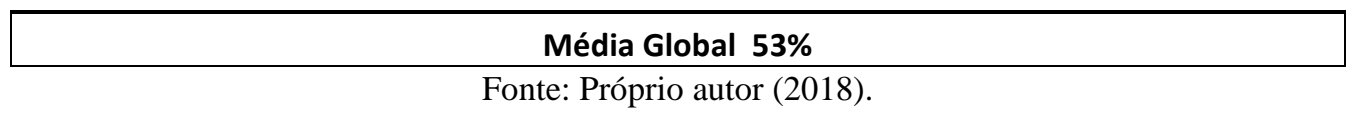

A seguir será avaliada cada questão do questionário, individualmente, para melhor entendimento dos maiores desafios encontrados. Com o intuito de avaliar os conhecimentos dos entrevistados sobre as situações mencionadas anteriormente, foram elaboradas sete afirmações, onde apenas 1 resposta é correta (elisão ou evasão). Seguem as informações coletadas na pesquisa em quadros com suas respectivas análises. A começar pela Tabela 3:

Tabela 3: Pergunta 1

1. Conforme a Lei complementar 116, referente ISS, os serviços de informática e congêneres são serviços que o Imposto de ISS é pago no local da sede do prestador de serviços. Neste contexto, a empresa de informática de grande porte que se envolve em contratos de altos valores, possui sua matriz localizada em um município com alíquota elevada de ISS. Como planejamento tributário, quando a alíquota de ISS é menor no local da prestação de serviço, a empresa monta uma sede de representação "Filial" e passa a emitir Nota Fiscal através da filial.

\begin{tabular}{|c|c|c|c|c|}
\hline $\begin{array}{c}\text { Quantidade de } \\
\text { respondentes } \\
\text { Equivalente a 99\% }\end{array}$ & $\begin{array}{c}\text { Quantidade } \\
\text { Respostas Elisão } \\
\text { Fiscal }\end{array}$ & $\begin{array}{c}\text { Porcentagem (\%) } \\
\text { Respostas Elisão } \\
\text { Fiscal }\end{array}$ & $\begin{array}{c}\text { Quantidade } \\
\text { Respostas Evasão } \\
\text { Fiscal }\end{array}$ & $\begin{array}{c}\text { Porcentagem } \\
\text { (\%) Respostas } \\
\text { Evasão Fiscal }\end{array}$ \\
\hline 85 & 52 & $56 \%$ & 33 & $44 \%$ \\
\hline
\end{tabular}

Fonte: Próprio autor (2018).

Com relação à primeira pergunta do questionário que se refere ao entendimento da Lei Complementar 116 sobre o ISS, obteve-se um resultado positivo quanto às respostas, em que a maioria dos respondentes indicou a alternativa correta de elisão fiscal. É importante ressaltar que um dos 86 entrevistados se esqueceu de responder à questão 1, por isso a quantidade total de respostas obtidas para esta questão foi de 85 .

O percentual de $56 \%$ dos entrevistados entende que é Elisão Fiscal, também denominado planejamento tributário devido à criação de uma filial da empresa, no município da prestação do serviço com o intuito de reduzir a carga tributária dela, uma vez que o município onde o serviço será realizado possui alíquota menor do que o município onde a matriz se encontra instalada. $\mathrm{O}$ mesmo conceito foi apresentado no referencial teórico deste estudo.

Entretanto, 44\% dos estudantes respondentes consideram evasão fiscal, ou seja, agir de forma ilícita por criar filial para pagar menos tributos municipais, que também pode ser considerado um percentual alto de erro, uma vez que se aproxima de $50 \%$.

Conforme Fonseca, Pilati e Theiss, (2015) De acordo com a Lei Complementar 116, Art. 3o, o serviço considera-se prestado e o imposto devido no local do estabelecimento prestador do serviço. Em seu Art. 4o considera-se estabelecimento prestador o local onde o contribuinte desenvolva a atividade de prestar serviços, de modo permanente ou temporário, e que configure unidade econômica ou profissional.

Hoje, a jurisprudência envolvida no ISS, sobre este tipo de serviço está dando ações favoráveis ao imposto ser pago no município onde a empresa constitui sede, conforme denominado Art. $4^{\circ}$ da Lei citada (SILVA, 2012).

Quando relacionadas as respostas por instituição de ensino, destaca-se a UNIP e os que não informaram instituição de ensino, pois para estes casos, o percentual de acerto foi superior ao de erro (16\% - acerto, $11 \%$ - erro, e $19 \%$ - acerto, $2 \%$ - erro, respectivamente).

Por outro lado, a ESAGS apresentou mais percentual de erro a acerto (9\% - erro, 6\% acerto), assim como os alunos da UNIFESP (22\% - erro, $15 \%$ - acerto).

Neste tipo de pesquisa, visto que os números de alunos entre as universidades selecionadas para a pesquisa não são homogêneos (assim como em termos de idade e semestre que estão cursando), entende-se que não é cabível a comparação de acerto/erro entre as universidades (idades 
e semestres do curso), dessa forma, as informações consideradas serão a relação acerto/erro, entre os alunos de cada universidade (idades e semestres do curso), individualmente.

No quesito idade, pôde ser notado que mesmo que a maioria dos entrevistados se encontra entre 21 e 30 anos. Para este grupo, 38\% acertam a questão referida, frente aos $32 \%$ que erraram a questão. Analisando os respondentes mais jovens (abaixo de 20 anos), foi verificado que 5\% acertaram versus os $8 \%$ que erraram. Para os grupos com maior faixa etária, temos que a faixa que compreende as idades de 31 a 40 anos acertaram $11 \%$ enquanto $3 \%$ erraram e que todos os respondentes com mais de 41 anos acertaram a questão, o que demonstra ainda mais que os respondentes com mais idade têm maiores chance de acerto por questões de maior contato com temas fiscais. O único estudante que não informou a idade acertou a questão.

Analisando erros e acertos por semestre de curso para a questão 1, podemos confirmar a teoria de que quanto mais próximo o estudante estiver da conclusão do curso, maior sua chance de acerto, uma vez que os alunos do $7^{\circ}$ e $8^{\circ}$ trimestre mais acertaram que erraram a questão $\left(7^{\circ}\right.$ semestre - $13 \%$ de acerto e $4 \%$ de erro, $8^{\circ}$ semestre $-32 \%$ de acerto e $26 \%$ de erro). Para os demais semestres, obtivemos a seguinte relação: $3^{\circ}$ semestre $\left(2 \%\right.$ de acerto e $1 \%$ de erro); $4^{\circ}$ semestre ( $4 \%$ de acerto e $2 \%$ de erro); $5^{\circ}$ semestre ( $0 \%$ de acerto e $1 \%$ de erro); $6^{\circ}$ semestre ( $3 \%$ de acerto e $6 \%$ de erro); $10^{\circ}$ semestre $(0 \%$ acerto e $1 \%$ de erro); Alunos que não informaram o semestre (3\% de acerto e $1 \%$ de erro).

Tabela 4: Pergunta 2

02. O serviço considera-se prestado e o imposto devido no local do estabelecimento prestador ou, na falta do estabelecimento, no local do domicílio do prestador, exceto nas hipóteses previstas nos incisos I a XXII (Lei Complementar 116 Art3). Uma empresa de serviços de saúde, assistência médica e congênere, decide mudar sua sede para o município vizinho, visando pagar ISS com uma alíquota menor.

\begin{tabular}{|c|c|c|c|c|}
\hline $\begin{array}{c}\text { Quantidade de } \\
\text { respondentes } \\
\text { Equivalente a 100\% }\end{array}$ & $\begin{array}{c}\text { Quantidade } \\
\text { Respostas Elisão } \\
\text { Fiscal }\end{array}$ & $\begin{array}{c}\text { Porcentagem (\%) } \\
\text { Respostas Elisão } \\
\text { Fiscal }\end{array}$ & $\begin{array}{c}\text { Quantidade } \\
\text { Respostas Evasão } \\
\text { Fiscal }\end{array}$ & $\begin{array}{c}\text { Porcentagem } \\
\text { (\%) Respostas } \\
\text { Evasão Fiscal }\end{array}$ \\
\hline 86 & 65 & $67 \%$ & 21 & $33 \%$ \\
\hline
\end{tabular}

Fonte: Próprio autor (2018).

$\mathrm{Na}$ segunda pergunta da pesquisa, o percentual de respondentes que considera correta a resposta elisão fiscal novamente foi acima de 50\%, com um grau bom de acertos, pelo percentual de $67 \%$ alcançado, que foi o mais alto obtido em todas as questões desta pesquisa. Todavia, $33 \%$ ainda consideram esta ação ilícita.

O motivo que levou um significativo percentual de estudantes a considerarem esta ação ilícita, não se sabe. Mas Zanluca (2014) esclarece que a lei não pró́be que os estabelecimentos escolham o lugar onde exercerão atividades, pois os contribuintes possuem liberdade de optar por aqueles mais convenientes a si, mesmo se a definição do local for exclusivamente com objetivos de planejamento fiscal.

Quando analisadas as respostas por instituição de ensino, o resultado é extremamente positivo, uma vez que todas as universidades (e até aqueles que não informaram a instituição de ensino), acertaram mais que erraram a questão, o que mostra que grande parte dos estudantes está ciente no que diz respeito à agir dentro da lei, pois na mudança da sede da empresa para outro município o imposto ISSQ pode ser cobrado no local do estabelecimento prestador. A universidade que mais se destaca, neste caso é a UNIP, onde possui $21 \%$ de acerto frente a $6 \%$ de erro, seguida pela UNIFESP ( $24 \%$ de acerto e $15 \%$ de erro), sem universidade informada ( $14 \%$ de acerto e $8 \%$ de erro) e ESAGS (8\% de acerto e $4 \%$ de erro).

No quesito idade, pôde-se notar que o resultado foi bem positivo nos grupos de "até 20", "de 21 a 30" e "de 31 a 40", visto que a relação de acerto em relação aos erros foi de $10 \%$ de acerto para $2 \%$ de erros, $44 \%$ de acertos para $26 \%$ de erros e $12 \%$ de acertos para $2 \%$ de erros, respectivamente. Para a faixa que compreende "mais que 41 anos", foi obtido $1 \%$ de erro para $1 \%$ de acerto e o único estudante que não informou a idade errou a questão. 
Continuando com a análise, desta vez entre os erros e acertos por semestre de curso, para a questão 2, podemos novamente confirmar a teoria de que quanto mais próximo o estudante estiver da conclusão do curso, mais chances tem de acertar o questionário. Para este caso, os alunos do $7^{\circ} \mathrm{e}$ $8^{\circ}$ trimestre mais acertaram que erraram a questão $\left(7^{\circ}\right.$ semestre $-10 \%$ de acerto e $7 \%$ de erro, $8^{\circ}$ semestre $-40 \%$ de acerto e $19 \%$ de erro).

Nesta questão também foi obtido $0 \%$ de erro entre os alunos de $3^{\circ}$ e $5^{\circ}$ semestres $\left(3^{\circ}\right.$ semestre $-3 \%$ acerto e $0 \%$ de erro, $4^{\circ}$ semestre $-6 \%$ de acerto e $0 \%$ de erro, $5^{\circ}$ semestre $1 \%$ de acerto e $0 \%$ de erro), o que mostra que há o entendimento e compreensão de que na mudança da sede da empresa para outro município o imposto ISS pode ser cobrado no local do estabelecimento prestador. Para os demais casos, obtivemos a seguinte relação: $6^{\circ}$ semestre $(6 \%$ de acerto e $3 \%$ de erro); $10^{\circ}$ semestre ( $0 \%$ de acerto e $1 \%$ de erro); e àqueles que não informaram o semestre $(2 \%$ de acerto e $2 \%$ de erro).

Na sequência, segue-se com a terceira pergunta, conforme apresentado na Tabela abaixo:

\section{Tabela 5: Pergunta 3}

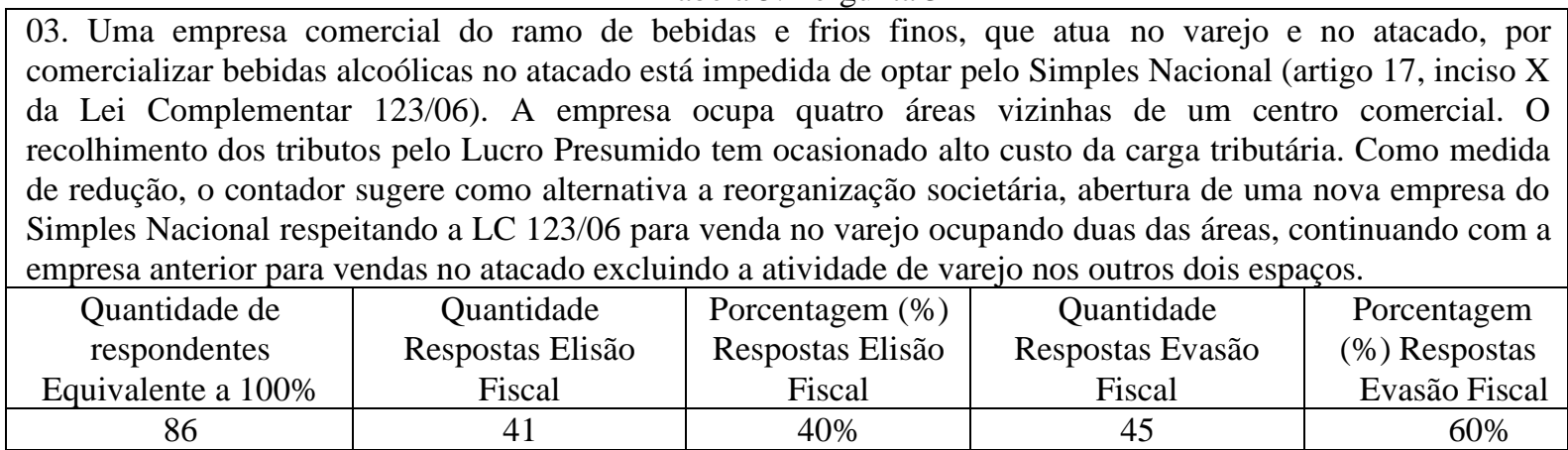

Fonte: Próprio autor (2018).

Com relação à terceira pergunta que trata de reorganização societária como forma de planejamento tributário, a maioria dos respondentes discordou da situação, representando um percentual de, $60 \%$, considerando um grau alto de erro, no entendimento de que esta situação é uma forma de planejamento tributário lícito, que é a alternativa certa. Apenas $40 \%$ dos estudantes consideraram a ação um método de elisão fiscal.

A opção de reorganização societária, por meio da criação de uma nova empresa optante pela forma de tributação Simples Nacional, para as vendas no varejo, resulta no recolhimento dos impostos com alíquota menor, o que torna a empresa mais competitiva no mercado (DE LUCA; TEIXEIRA FILHO; CORRÊA, 2007).

Para que a reorganização societária seja considerada planejamento tributário lícito, deve ser respeitada a Lei Complementar 123/06, com a realização da separação dos espaços físicos, quadro de funcionários independente, grau de parentesco dos sócios e demais exigências que a legislação impõe. Caso não sejam respeitadas essas condições, tal procedimento é ilegal (Fonseca, Pilati, Theiss, 2015).

Ao relacionar as respostas por instituição de ensino, ao contrário da questão 2, foi constatado que em todos os casos o percentual de erro foi maior que o de acerto. Dessa forma temos a seguinte relação de acerto e erro: ESAGS (9\% de erro e 3\% de acerto); Estudantes que não informaram a instituição de ensino (15\% erro e $7 \%$ de acerto); UNIFESP (23\% de erro e $16 \%$ de acerto) e UNIP ( $14 \%$ de erro e $13 \%$ de acerto)

Um dos fatores que pode ter causado confusão nas respostas, pode ser a falta de explicação em aulas sobre tópicos como reorganização societária e seus impactos tributários.

No que tange à análise das respostas por faixa etária, temos que o único percentual positivo de acertos em relação aos erros pode ser observado na faixa que compreende de "31 aos 40 anos", 
onde o acerto foi de $8 \%$, frente aos $6 \%$ de erro para a mesma questão, o que confirma ainda mais que a idade pode influenciar no discernimento fiscal do indivíduo.

Para os demais casos, foi identificada a seguinte relação de erro versus acerto: "até 20 " $(10 \%$ erro e $6 \%$ de acerto); "de 21 a 30 " (42\% de erro e $28 \%$ de acerto); "mais que 41 " (1\% de erro e $1 \%$ de acerto) e para aquele que não informou a idade, temos $1 \%$ de erro frente a $0 \%$ de acerto.

Ao relacionar as respostas da questão com o semestre de curso de graduação, temos que o $8^{\circ}$ e $5^{\circ}$ semestres obtiveram um nível de acerto superior aos erros para o caso de reorganização societária ( $31 \%$ de acerto para $26 \%$ de erro e $1 \%$ de acerto para $0 \%$ de erro, respectivamente). Para os demais casos, as quantidades de erros foram superiores às quantidades de acertos, conforme demonstrado a seguir: $3^{\circ}$ semestre $\left(0 \%\right.$ de acerto para $3 \%$ de erro); $4^{\circ}$ semestre $(4 \%$ de erro para $2 \%$ de acerto); $6^{\circ}$ semestre ( $8 \%$ de erro para $2 \%$ de acerto); $7^{\circ}$ semestre (14\% de erro para $3 \%$ de acerto); $10^{\circ}$ semestre ( $1 \%$ de erro para $0 \%$ de acerto); Estudantes que não informaram o semestre de graduação ( $4 \%$ de erro para $1 \%$ de acerto).

Seguindo a temática de reorganização societária, segue a quarta pergunta da pesquisa, de acordo com o Quadro 5, conforme exposto a seguir.

Tabela 6: Pergunta 4

04. Conforme Lei Complementar 123/06, as alíquotas do Simples Nacional são progressivas de acordo com o valor do faturamento acumulado nos últimos 12 meses. Para diminuir a carga tributária, determinada empresa através da reorganização societária optou em desmembrar as atividades antes exercidas por uma delas, instalando duas empresas optantes pelo Simples Nacional na mesma área geográfica. Ambas as sociedades empresariais possuem registros e inscrições fiscais próprias, quadro de funcionários diferentes e celebração de negócios separadamente.

\begin{tabular}{|c|c|c|c|c|}
\hline $\begin{array}{c}\text { Quantidade de } \\
\text { respondentes } \\
\text { Equivalente a 100\% }\end{array}$ & $\begin{array}{c}\text { Quantidade } \\
\text { Respostas Elisão } \\
\text { Fiscal }\end{array}$ & $\begin{array}{c}\text { Porcentagem (\%) } \\
\text { Respostas Elisão } \\
\text { Fiscal }\end{array}$ & $\begin{array}{c}\text { Quantidade } \\
\text { Respostas Evasão } \\
\text { Fiscal }\end{array}$ & $\begin{array}{c}\text { Porcentagem } \\
\text { (\%) Respostas } \\
\text { Evasão Fiscal }\end{array}$ \\
\hline 86 & 47 & $48 \%$ & 39 & $52 \%$ \\
\hline
\end{tabular}

Fonte: Próprio autor (2018).

A quarta pergunta refere-se ao desmembrando das atividades de uma empresa do Simples Nacional, com a criação de uma nova empresa, na mesma área geográfica, com o intuito de redução da alíquota do Simples Nacional, tendo em vista que ela é progressiva, de acordo com o faturamento dos últimos 12 meses. A pesquisa resultou em um grau baixo de acerto com uma porcentagem de $48 \%$ de acertos, que consideram a situação Elisão Fiscal, frente a 52\% que entendem que se trata de evasão fiscal.

Quanto aos cuidados na separação dos espaços físicos, com intuito de evitar autuações da Receita Federal, no estudo de Dalmagro e Martins (2010) foi considerada lícita à forma de planejamento tributário, embora a empresa tenha tido problemas com a Receita Federal.

Ao analisar as repostas por universidades, temos que apenas para a UNIP o nível de acerto foi levemente mais alto que o de erro (14\% de acerto para $13 \%$ de erro), para as demais universidades e para os respondentes que não informaram instituição de ensino, o nível de erro foi superior ao de acerto (ESAGS - 7\% de erro para 5\% de acerto; Não informado - 13\% de erro para 9\% de acerto; UNIFESP - $21 \%$ de erro para $18 \%$ de acerto). Esses resultados só demonstram, assim como na questão 3 , como o tópico de reorganização societária pode ser mais bem abordado nas instituições de ensino, pois, mesmo o enunciado clarificando que as sociedades empresariais possuem registros e inscrições fiscais próprias, quadro de funcionários diferentes e celebração de negócios separadamente, os estudantes ainda configurariam este caso como evasão fiscal.

Quando analisadas as repostas por faixa etária temos que o público mais velho teve o percentual de acerto acima do percentual de erro ("de 31 a 40 " - 8\% de acerto para 6\% de erro; "mais que 41 " - $2 \%$ de acerto para $0 \%$ de erro), enquanto o público mais jovem e o que não informou idade teve um percentual de erro superior ao de acerto ("até 20 " $-8 \%$ de erro pra $5 \%$ de acerto; "de 21 a 30" - 38\% de erro para 32\% de acerto; Não informado - $1 \%$ de erro para $0 \%$ de acerto). 
Analisando as repostas obtidas por semestre do curso de graduação, temos que o $3^{\circ}, 4^{\circ}$ e $8^{\circ}$ semestres, foram os que obtiveram um nível de resposta ligeiramente maior que o nível de erro (2\% de acerto e $1 \%$ de erro; $4 \%$ de acerto e $2 \%$ de erro; $30 \%$ de acerto e $28 \%$ de erro, respectivamente). Para os demais semestres e até mesmo os que não informaram o semestre de graduação, os percentuais de erro estão acima dos acertos $\left(5^{\circ}\right.$ semestre $-1 \%$ de erro e $0 \%$ de acerto; $6^{\circ}$ semestre $5 \%$ de erro e $4 \%$ de acerto; $7^{\circ}$ semestre $-11 \%$ de erro e $6 \%$ de acerto; $10^{\circ}$ semestre $-1 \%$ de erro e $0 \%$ de acerto e os que não informaram o semestre de graduação empatou a resposta em $2 \%$ de erro com $2 \%$ de acerto).

Prossegue-se a sequência de questionários com a questão 5, a qual também trata de reorganização societária:

Tabela 7: Pergunta 5

\begin{tabular}{|c|c|c|c|c|}
\hline $\begin{array}{c}\text { Quantidade de } \\
\text { respondentes } \\
\text { Equivalente a } 100 \%\end{array}$ & $\begin{array}{c}\text { Quantidade } \\
\text { Respostas Elisão } \\
\text { Fiscal }\end{array}$ & $\begin{array}{c}\text { Porcentagem (\%) } \\
\text { Respostas Elisão } \\
\text { Fiscal } \\
\end{array}$ & $\begin{array}{c}\text { Quantidade } \\
\text { Respostas Evasão } \\
\text { Fiscal } \\
\end{array}$ & $\begin{array}{l}\text { Porcentagem } \\
(\%) \text { Respostas } \\
\text { Evasão Fiscal } \\
\end{array}$ \\
\hline 86 & 29 & $38 \%$ & 57 & $62 \%$ \\
\hline
\end{tabular}

Fonte: Próprio autor (2018).

Refere-se à criação de três empresas optantes pelo Simples, com intuito de não ultrapassar o valor limite de faturamento que permite a opção pelo regime, a pesquisa obteve um percentual relativamente elevado de respostas que considera a ação ilícita, ou seja, Evasão fiscal (62\%), e 38\% entendem que a ação é lícita, permitida por lei.

Para justificar e referenciar o entendimento desta situação ser considerada evasão fiscal, citase a Ação Penal No 5001974-53.2011.404.7113/RS (2013), na qual determinada empresa, foi denunciada e autuada por atuar com três empresas, optantes pelo regime de tributação Simples Federal, forma de tributação do Simples do período, até 2006 (Fonseca, Pilati, Theiss, 2015).

Eles ainda explicam que,

$\mathrm{Na}$ referenciada situação, a fiscalização considerou falsidade nas declarações que informavam que a empresa era optante do Simples, na qual ficou evidente a criação das empresas para que não ultrapassasse o valor limite para opção, quando na verdade tratavase de uma única empresa. Ambas eram administradas pela mesma pessoa, através de procuração, e diversos outros indícios que não deixaram dúvida quanto intenção ilícita na redução dos tributos, principalmente previdenciários .

O réu foi denunciado pela prática de fato enquadrado na Lei n. 8.137/90, no seguinte dispositivo: Art. $1^{\circ}$ "Constitui crime contra a ordem tributária suprimir ou reduzir tributo, ou contribuição social e qualquer acessório, mediante as seguintes condutas: omitir informação, ou prestar declaração falsa às autoridades fazendárias; (...) Pena reclusão de 2 (dois) a 5 (cinco) anos, e multa”. (Fonseca, Pilati, Theiss, 2015).

Conforme os dispositivos da Lei citada, a situação da quinta questão é claramente considerada evasão fiscal, economia de tributos ilícita.

Analisando as respostas obtidas dos estudantes a partir da Instituição de ensino, apenas para o caso em que os estudantes não informaram a universidade de estudo o percentual de erro foi acima que o de acerto (12\% de erro para $10 \%$ de acerto). Para os demais casos, felizmente, o percentual de acerto foi superior ao de erro (ESAGS - $11 \%$ de acerto para $1 \%$ de erro; UNIFESP $21 \%$ de acerto para $18 \%$ de erro; UNIP - $19 \%$ de acerto para $8 \%$ de erro), o que demonstra que embora nas questões anteriores de reorganização societária tenha sido obtido um resultado negativo, ainda foi obtida uma questão positiva para esta temática. 


\section{Contabilidade}

Ao analisar a faixa etária respondente relacionada aos acertos, temos que quase todas as faixas obtiveram maiores acertos que erros, exceto a faixa que não informou a idade e a que possui mais que 41 anos, embora elas sejam pouco representativas em relação ao total (3\%). '

Dando sequência a análise dos resultados, foi obtido que a faixa "até 20 anos", obteve $10 \%$ de acerto para $3 \%$ de erro, a faixa "de 21 a 30 " teve $42 \%$ de acerto para $28 \%$ de erro e a que compreende "de 31 a 40", obteve $11 \%$ de acerto para $3 \%$ de erro, o que demonstra que o estudante pode diferenciar as situações de elisão e evasão, onde as questões apresentadas apenas se referiram ao primeiro método até o momento.

Ao tratar do nível de acerto dos respondentes no quesito semestre da graduação, temos que todas as categorias mais acertaram que erraram, com exceção do aluno do $10^{\circ}$ semestre, que obteve $1 \%$ de erro frente a $0 \%$ de acerto, mas, mesmo assim, podemos inferir que houve um percentual alto de dúvidas no, principalmente para o $8^{\circ}$ semestre, pois a diferença entre erro e acerto foi pequena nesse grupo (30\% de acerto para $28 \%$ de erro), conforme demonstrado a seguir. Temos que para o $3^{\circ}$ semestre o acerto foi de $3 \%$ e erro $0 \% ; 4^{\circ}$ semestre o acerto foi de $6 \%$ e erro $0 \% ; 5^{\circ}$ semestre o acerto foi de $1 \%$ e erro $0 \% ; 6^{\circ}$ semestre $6 \%$ de acerto e $3 \%$ de erro; $7^{\circ}$ semestre, $13 \%$ de acerto e $4 \%$ de erro; para os que não informaram o semestre do curso foi obtido $3 \%$ de acerto para $2 \%$ de erro.

Em situação semelhante a da quinta pergunta, a pesquisa apresentou a sexta pergunta, que também se refere à criação de mais de uma empresa com o intuito de reduzir tributos.

Tabela 8: Pergunta 6

\begin{tabular}{|c|c|c|c|c|}
\hline $\begin{array}{c}\text { Quantidade de } \\
\text { respondentes } \\
\text { Equivalente a 100\% }\end{array}$ & $\begin{array}{r}\text { Quantidade } \\
\text { Respostas Elisão } \\
\text { Fiscal }\end{array}$ & $\begin{array}{c}\text { Porcentagem (\%) } \\
\text { Respostas Elisão } \\
\text { Fiscal }\end{array}$ & $\begin{array}{c}\text { Quantidade } \\
\text { Respostas Evasão } \\
\text { Fiscal }\end{array}$ & $\begin{array}{l}\text { Porcentagem } \\
\text { (\%) Respostas } \\
\text { Evasão Fiscal }\end{array}$ \\
\hline 86 & 32 & $43 \%$ & 54 & $57 \%$ \\
\hline
\end{tabular}

Fonte: Próprio autor (2018).

A pesquisa obteve um percentual acima de $50 \%$ que respondeu o questionamento corretamente, mas o percentual ainda se encontra muito próximo à média que consideram a criação de mais de uma empresa para economia de tributos, visto que $43 \%$ dos respondentes consideram uma ação lícita e devida.

Conforme pergunta, que considera ilícita a criação de duas empresas com mesmo objeto social, no mesmo espaço físico, que utilizam os mesmos colaboradores e funcionários com intenção de usufruir de tributação privilegiada. De acordo com Acórdão $N^{\circ}$ 06-26037 de 01 de Abril de 2010, a situação acima é considerada constituição de grupo econômico e realizada a revisão e exclusão do simples com efeito retroativo (Fonseca, Pilati, Theiss, 2015).

A pesquisa mostra que os estudantes não possuem tanto discernimento quando se trata da legislação quanto a não permissão destas formas de redução de tributos.

Se tratando das respostas a nível de instituição de ensino, temos que nos casos do ESAGS e dos que não informaram a instituição de ensino foi constatado um nível de acerto superior ao nível de erro (9\% de acerto e $4 \%$ de erro e $14 \%$ de acerto e $8 \%$ de erro, respectivamente), para os casos da UNIFESP e da UNIP, os percentuais se mantiveram muito próximos ou quase iguais (20\% de acerto para $19 \%$ de erro e $13 \%$ de acerto para $13 \%$ de erro, respectivamente). A partir dessa questão, retomamos a ideia de que o tópico de organização societária pode ser mais bem tratado nas universidades uma vez que é visível que os estudantes têm certas dificuldades neste assunto.

Para análise de respostas por faixa etária, foi obtido destaque nas respostas do grupo que compreende dos 21 aos 30 anos, pois foi apurado um percentual de $47 \%$ de acerto, frente a $23 \%$ de erro, o que um resultado bem interessante, pois além de ser a faixa com maior número de 
respondentes, foi a que alavancou o percentual de respostas para $57 \%$ de acerto, uma vez que as demais faixas não apresentaram um bom desempenho. A faixa de "até 20 anos" apresentou 10\% de erro para 3\% de acerto, a faixa de "31 a 40" apresentou para acertos e erros o mesmo percentual (7\%), a faixa que engloba o grupo acima de 41 anos apresentou $2 \%$ de erro para $0 \%$ de acerto e a que não informou idade errou a questão ( $1 \%$ de erro para $0 \%$ de acerto).

Ao verificar o nível de acerto por semestre da graduação, foi observado que o $7^{\circ}$ e $8^{\circ}$ semestres possuíram um percentual de acerto acima dos erros (11\% de acerto e 6\% de erro e $36 \%$ de acerto e $22 \%$ de erro, respectivamente), enquanto os demais grupos não apresentaram um desempenho muito significativo $\left(3^{\circ}\right.$ semestre $-2 \%$ de erro e $1 \%$ de acerto; $4^{\circ}$ semestre $-4 \%$ de erro e $2 \%$ de acerto; $5^{\circ}$ semestre $-1 \%$ de acerto e $0 \%$ de erro; $6^{\circ}$ semestre $-5 \%$ de erro e $4 \%$ de acerto; $10^{\circ}$ semestre $-1 \%$ de erro e $0 \%$ de acerto; Semestre não informado $-3 \%$ de erro e $2 \%$ de acerto).

Segue a sétima e última pergunta da pesquisa, que referencia uma situação inversa às perguntas anteriores, de acordo com o Quadro 7.

\section{Tabela 9: Pergunta 7}

07. Determinado grupo econômico, constituído por várias empresas optantes pelo Simples Nacional, com estrutura autônoma tanto formal como material exercem atividade econômica organizada de forma independente da empresa controladora.

\begin{tabular}{|c|c|c|c|c|}
\hline $\begin{array}{c}\text { Quantidade de } \\
\text { respondentes } \\
\text { Equivale a 100\% }\end{array}$ & $\begin{array}{c}\text { Quantidade } \\
\text { Respostas Elisão } \\
\text { Fiscal }\end{array}$ & $\begin{array}{c}\text { Porcentagem (\%) } \\
\text { Respostas Elisão } \\
\text { Fiscal }\end{array}$ & $\begin{array}{c}\text { Quantidade } \\
\text { Respostas Evasão } \\
\text { Fiscal }\end{array}$ & $\begin{array}{c}\text { Porcentagem } \\
\text { (\%) Respostas } \\
\text { Evasão Fiscal }\end{array}$ \\
\hline 86 & 44 & $44 \%$ & 42 & $56 \%$ \\
\hline
\end{tabular}

Fonte: Próprio autor (2018).

Conforme Rizzi (2014) explica, a constituição de várias empresas optantes pelo Simples Nacional, com estrutura formal e material independente, pode ser considerada Elisão Fiscal.

A pesquisa obteve um nível muito baixo de acerto (44\%), que consideram Planejamento Tributário legal a referida situação. Por outro lado, 56\% dos respondentes consideram a situação indevida e ilícita.

A pergunta 07 finaliza o questionário aplicado e mostra que, por meios legais, o Planejamento Tributário pode reduzir a carga tributária de maneira organizada.

Contudo, este processo exige conhecimento e entendimento da Legislação, principalmente da Lei 104/2001, que em seu art.116, parágrafo único, trata da norma anti-elisiva, criada para evitar situações de elisão abusivas (Fonseca et al, 2015).

Ao analisar a respostas obtidas por categorias, temos que, a nível de instituição de ensino, nenhuma universidade apresentou mais acertos em relação aos erros, mas alguns empates foram identificados, como nos casos da UNIP e daqueles que não informaram o local de estudo (13\% para acertos e erros e $11 \%$ para acertos e erros, respectivamente). Para a UNIFESP e ESAGS foi obtido $7 \%$ de acerto $6 \%$ de erro e $26 \%$ de erro e $13 \%$ de acerto, respectivamente.

Ao ver esse baixo percentual de acerto, podemos notar que, de fato, as temáticas relacionadas à reorganização societária podem ser melhor abordadas nas universidades, visto que a questão 5, que possui temática similar, foi a que obteve o resultado mais positivo, mas ainda assim apresentou um alto índice de erro.

Em relação às respostas por faixa etária, pode-se observar que as únicas faixas que apresentaram resultados positivos foram as de "até 20 " - $8 \%$ de acerto para $5 \%$ de erro, "mais que 41 " $-2 \%$ de acerto e $0 \%$ de erro, e "Faixa não informada" - $1 \%$ de acerto e $0 \%$ de erro.

Para as demais faixas, o erro foi bem superior ao acerto, conforme demonstrado; "de 21 a $30 "-42 \%$ de erro e $28 \%$ de acerto e "de 31 a $40 "-9 \%$ de erro e $5 \%$ de acerto.

Os resultados obtidos por semestre do curso mostram que, curiosamente, os primeiros semestres foram os únicos que apresentaram um resultado positivo, o que também pode demonstrar certa falta atenção na leitura do questionário por parte dos demais semestres. No caso, foi o $3^{\circ}$ e $4^{\circ}$ 


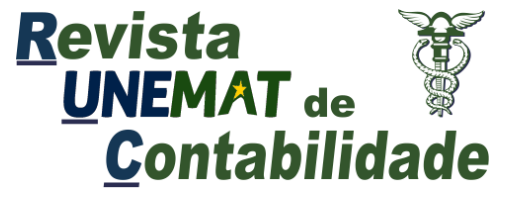

v. 9, n. 18,2020

semestre que apresentaram dados positivos (3\% de acerto para $0 \%$ de erro e $4 \%$ de acerto para $1 \%$ de erro, respectivamente). Os demais semestres apresentaram mais erros que acertos, conforme pode ser observado abaixo.

Após evidenciação e comentários das respostas obtidas para as simulações das situações de elisão e evasão fiscal, foi aberto, ainda no questionário, uma seção onde o estudante poderia indicar até 5 pontos de melhoria no ensino de Contabilidade Tributária.

Vale destacar que as respostas dessa seção eram opcionais, dessa forma, foi apurado que 36 dos 86 estudantes elencaram pelo menos uma sugestão de melhoria.

De todas as sugestões obtidas, as que foram mais recorrentes são as que explicam que a carga horária de ensino em Contabilidade Tributária pode ser aumentada no curso de Ciências Contábeis, o que demonstra que de fato, há a sensação por parte dos alunos de que a carga proposta na grade do curso não é suficiente para atender a complexidade da temática.

Outra sugestão muito recorrente diz respeito à exposição de casos reais e seus desdobramentos durante às aulas, com aplicação de exercícios práticos e debates, pra que assim o aluno possa vivenciar experiências em que um pensamento crítico no que diz sobre a Legislação Tributária também se faz necessário, e não apenas o simples conhecimento das leis por si só. Isso também diz muito sobre como os exercícios práticos podem facilitar o entendimento do estudante que está tendo contato com temas relacionados ao fisco pela primeira vez, tendo em vista que as leis brasileiras, além de serem extremamente complexas, estão em constante mudança, o que faz com que tanto o profissional formado quanto o em formação, estejam cada vez mais atualizados sobre as normas vigentes.

Alguns alunos também mencionaram a qualificação do professor de Contabilidade Tributária, que pode ser aperfeiçoada, assim como as metodologias de ensino aplicadas.

\section{CONCLUSÃO}

A partir do que foi evidenciado no trabalho, é possível afirmar que ele atingiu os objetivos previamente propostos. Por meio dos dados coletados na revisão de literatura, foi possível estabelecer uma discussão a respeito do conhecimento dos estudantes de contabilidade sobre situações de elisão e evasão fiscal e da sua importância para a sua formação. Desenvolveu-se, para tanto, uma pesquisa descritiva por meio de perguntas abertas e fechadas, com análise de dados quantitativos.

Através de uma amostra válida composta por 86 estudantes da Grande São Paulo, de diferentes idades, instituições de ensino e semestre do curso de Ciências Contábeis, foi possível estimar quais temas são de maior entendimento e discernimento entre legalidade e ilegalidade perante a Legislação brasileira. Foi verificado que a maioria dos respondentes se encontram entre os 21 e 30 anos de idade (70\%) e na segunda metade do curso de graduação (76\%). As universidades onde a pesquisa foi realizada foram ESAGS, UNIP e UNIFESP, todas localizadas na Grande São Paulo.

Para a primeira pergunta sobre a utilização de planejamento tributário, com o objetivo de redução de ISS, $56 \%$ das respostas correspondem à alternativa correta. Na segunda pergunta, ainda sobre situações de elisão fiscal através do ISS, o percentual de acerto foi de $67 \%$, que foi o grau de acerto mais elevado para toda a pesquisa.

Da terceira à sétima pergunta, o assunto abordado foi referente à reorganização societária. Nas questões para tal temática, o nível de acerto não foi satisfatório, embora em algumas das questões o resultado tenha se apresentado de forma levemente positiva.

$\mathrm{Na}$ terceira pergunta que abordou o planejamento tributário por meio de desmembramento de atividades e abertura de duas empresas, houve um percentual de $40 \%$ de acerto, que foi o mais baixo de todo o questionário, o que levou a uma conclusão de que possivelmente a temática de reorganização societária não está sendo devidamente ministrada nos cursos, o que faz com que 
surjam um série de dúvidas neste assunto. A quarta pergunta obteve um percentual semelhante, de $48 \%$ de respostas, que considera elisão fiscal ou economia tributária lícita à instalação de duas empresas do Simples Nacional na mesma área geográfica, o que também é um resultado preocupante, por se encontrar abaixo da média esperada. A quinta pergunta se trata da criação de três empresas do mesmo ramo de atividade, para se manter como integrante do regime de tributação Simples Nacional. Neste caso, $62 \%$ dos respondestes consideraram corretamente evasão fiscal. A constituição de grupo econômico, para usufruir de tributação privilegiada (Simples Nacional), objeto da sexta pergunta, obteve $57 \%$ de respostas que considera a situação evasão fiscal, considerado um nível de acerto razoável.

Para finalizar, a pergunta sete, obteve um percentual de $44 \%$ que consideram a situação elisão fiscal, resultando em um grau de acerto muito baixo.

Após análise das respostas obtidas, conclui-se que um pouco mais da metade dos estudantes de contabilidade possuem conhecimento da legislação em relação a situações elisivas e evasivas.

Assim, foi identificado através do estudo que o nível de conhecimento fiscal da amostra não é muito satisfatório, o que pode se relacionar com alguns fatores, como a baixa idade dos respondentes, que ainda não vivenciaram muitas situações práticas onde o conhecimento fiscal foi necessário, mesmo que a grande maioria dos estudantes se encontrem na segunda metade do curso de graduação.

O estudantes ainda alegaram que falta no decorrer das aulas, as aplicações de exercícios práticos e debates para desenvolvimento de maior senso crítico para essas questões, bem como foi questionada a formação dos professores de Contabilidade Tributária.

Essas dúvidas e interpretações equivocadas podem proporcionar como consequência, a realização de planejamento tributário de forma evasiva. Por meio dos resultados encontrados, reforça-se a importância da qualificação dos profissionais de contabilidade por meio da educação continuada.

Considera-se a temática de suma relevância no meio acadêmico e empresarial, devido à necessidade da qualificação dos profissionais de contabilidade para um melhor conhecimento em situações práticas de planejamento tributário, principalmente para atender às demandas do mercado de trabalho. Assim, foi possível reperformar o estudo de Fonseca, Pilati e Theiss, numa diferente zona geográfica, considerando um diferente tipo de amostra. Assim, recomenda-se ainda mais que este tipo de estudo seja replicado, buscando conclusões mais robustas no que tange ao conhecimento do futuro profissional de contabilidade.

\section{REFERÊNCIAS}

ABRAHÃO, Marcelo Alcântara. A Elisão Fiscal como Ferramenta para o Planejamento Tributário. Santa Catarina, 2011. Disponível em r https://repositorio.ufsc.br/bitstream/handle/123456789/121033/295994.pdf?sequence=1\&isAllowed $=\mathrm{y}>$. Acesso em 30 mar..2018.

BENICIO, Francinildo Carneiro. PORTELA, Francisco das Chagas Rodrigues. Planejamento Contábil Tributário como ferramenta para redução legal dos tributos. 2017. Disponível em $<$ https://semanaacademica.org.br/system/files/artigos/artigo_planejamento_tributario_29.09.2017.p df $>$. Acesso em 26 mai. 2018

BRASIL. Ação Penal No 5001974-53.2011.404.7113/RS. Ministério Público Federal. Sentença. 2013. Disponível em: <http://s.conjur.com.br/dl/vara-federal-bento-goncalves-rs-condena.pdf. >Acesso em 11 nov. 2018.

BRASIL. Acórdão no 06-26037, de 01 abr. 2010. Delegacia da Receita Federal de Julgamento em Curitiba, $2^{\circ}$ turma. Disponível em: < https://goo.gl/UiEW4f>. Acesso em 11 nov. 2018. 
BRASIL. Constituição da República Federativa do Brasil de 1988. Disponível em < http://www.planalto.gov.br/ccivil_03/constituicao/constituicao.htm>. Acesso em 26 mai. 2018.

BRASIL. Lei $\mathbf{n}^{\mathbf{0}}$ 5.172, de 25 de outubro de 1966. Dispõe sobre o Sistema Tributário Nacional e institui normas gerais de direito tributário aplicáveis à União, Estados e Municípios.. Disponível em <http://www.planalto.gov.br/ccivil_03/Leis/L5172.htm>. Acesso em 26 mai. 2018

BRASIL. Lei $\mathrm{n}^{\circ}$ 8.137, de 27 de dezembro de 1990. Define crimes contra a ordem tributária, econômica e contra as relações de consumo, e dá outras providências. Disponível em < http://www.planalto.gov.br/ccivil_03/LEIS/L8137.htm>. Acesso em 24 nov.2018.

BRASIL. Receita Federal - dados do CTB em relação ao PIB,. Disponível em <http://idg.receita.fazenda.gov.br/noticias/ascom/2017/dezembro/carga-tributaria-bruta-atingiu-3238-do-pib-em-2016>. Acesso em 30 mar. 2018

BRASIL. Receita Federal - dados do CTB em relação ao PIB (arquivo completo). Disponível em <http://idg.receita.fazenda.gov.br/dados/receitadata/estudos-e-tributarios-e-aduaneiros/estudose-estatisticas/carga-tributaria-no-brasil/carga-tributaria-2016.pdf> Acesso em 30 mar. 2018

CARDOSO, Bruno. Saiba o que é tributo e quais são suas espécies. Mato Grosso do Sul, 2017. Disponível em < https://brunonc.jusbrasil.com.br>. Acesso em 26 mai..2018

CERA, Denise Cristina Mantovani. A obrigação tributária principal e a obrigação tributária acessória devem necessariamente estar previstas em lei?. Disponível em $<$ https://lfg.jusbrasil.com.br/noticias/2394597/a-obrigacao-tributaria-principal-e-a-obrigacaotributaria-acessoria-devem-necessariamente-estar-previstas-em-lei-denise-cristina-mantovani-cera >. Acesso em 26 mai. 2018

CFC 1.60/05 NBC P4. Disponível em <http://www.portaldecontabilidade.com.br/nbc/res995.htm>. Acesso em 26 mai.2018

DALMAGRO, Diego Vitor; MARTINS, Simone. A Reestruturação Societária como ferramenta do Planejamento Tributário. Rio Grande do Sul, 2011. Disponível em:〈http://works.bepress.com/cgi/viewcontent.cgi?article=1021\&context=simone_martins $>$.

Acesso em: 11 nov. 2018.

DE LUCA, Márcia; TEIXEIRA F., Marcelo C.; CORRÊA, Denise M. M. C. A Elisão Tributária aplicada ás Micro e Pequenas empresas. Ceará, 2007. Disponível em:<http://www.congressousp.fipecafi.org/web/artigos72007/329.pdf >. Acesso em: 24 nov. 2018.

DUTRA, Fabio. 2018. Código Tributário Nacional Esquematizado. Disponível em <https://www.slideshare.net/FabioDutra2/slides-da-aula-curso-intensivo-stj>. Acesso em 26 mai. 2018

FABRETTI, Láudio Camargo. Contabilidade Tributária. 9 ed. São Paulo: Atlas, 2005.

GIL, Antonio Carlos. Métodos e técnicas de pesquisa social. 6 ed. São Paulo: Atlas, 2010.

LUNELLI, Reinaldo Luiz. A contabilidade e o avanço da tecnologia. Disponível em <http://www.portaldecontabilidade.com.br/tematicas/contabilidadeetecnologia.htm>. Acesso em 26 mai. 2018

MALHOTRA, NARESH K.. Pesquisa de marketing . 3 ed. Porto Alegre: Bookman, 2001.

MICHAELIS. Disponível em

http://michaelis.uol.com.br/busca?r=0\&f=0\&t=0\&palavra=evas\%C3\%A3o>. Acesso em 23 nov.2018

NASCIMENTO, Arlete. Explicando diferenças tributárias: impostos, taxas e contribuições. São Paulo, 2018. Disponível em: <https://pt.linkedin.com/pulse/explicando-diferen\%C3\%A7astribut\%C3\%A1rias-impostos-taxas-e-arlete-nascimento>. Acesso em 26 mai. 2018

OLIVEIRA ,Gustavo Pedro. Contabilidade Tributária .4 ed. São Paulo: Saraiva, 2013.

FONSECA, Marcos Wagner; PILATI, Rosimeri Horn; THEISS, Viviane;. Identificação de situações de elisão e evasão fiscal: um estudo com contadores no estado de Santa Catarina. Santa Catarina, 2015. Disponível em <http://revista.crcsc.org.br/index.php/CRCSC/article/view/2220/1903>. Acesso em 26 mai. 2018 


\section{Contabilidade}

POHLMANN, Marcelo Colleto. Contabilidade Tributária. IESDE Brasil S.A.,2010. Disponível em < https://www.passeidireto.com/arquivo/31331061/contabilidade-tributaria>. Acesso em 30 mar. 2018

RIZZI, Ângela Onzi. Limites do Planejamento Tributário: Diferença entre elisão e evasão fiscal. Rio Grande do Sul, 2014. Disponível em $<$ http://www.conteudojuridico.com.br/artigo,limites-do-planejamento-tributario-diferencasentreelisao-e-evasao-fiscal,46906.html>. Acesso em 26 mai. 2018

RICHARDSON, Roberto Jerry. Pesquisa Social: métodos e técnicas. 2. ed. São Paulo: Atlas, 1989.

SILVA, Samara dos Santos. Sistema tributário nacional: fiscalidade, parafiscalidade e extrafiscalidade. Campina Grande, 2014. Disponível em $<$ https://saamssilva.jusbrasil.com.br/artigos/119871459/sistema-tributario-nacional-fiscalidadeparafiscalidade-e-extrafiscalidade>. Acesso em 26 mai. 2018 SILVA, Leonardo Pacheco. A importância do Planejamento Tributário aplicado à função gerencial nas organizações. Minas Gerais, 2012. Disponível em < https://pt.slideshare.net/LeonardoPachecoSilva/artigo-cientfico-25860693>. Acesso em 30 mar. 2018

SOARES, Silveira. Impostos, taxas, contribuições: você sabe a diferença?. 2017. Disponível em $<$ http://www.silveirasoares.com.br/noticia-detalhe/39/impostos-taxas-contribuicoes-voce-sabe-adiferenca>. Acesso em 26 mai. 2018

SOUZA, Talita Cristina da Silva; NISHINA, Cristina da Silva; VIEIRA, Ricardo Tanaka. Planejamento Tributário - Elisão e Evasão Fiscal. Minas Gerais, 2016. Disponível em < http://revista.facfama.edu.br/index.php/ROS/article/view/144/155>. Acesso em 26 mai. 2018 TOM, Carin. Elisão fiscal: pague menos sem sonegar impostos. Disponível em < https://blog.contaazul.com/elisao-fiscal-pagar-menos-sonegar-impostos>. Acesso em 26 mai. 2018 ZANLUCA, Júlio Cesar. Planejamento Tributário. São Paulo, 2018. Disponível em: <http://www.portaltributario.com.br/planejamento.htm>. Acesso em: 26 mai. 2018. 